\title{
Perizinan dalam Pelestarian Cagar Budaya
}

\author{
Fr. Dian Ekarini \\ Balai Konservasi Borobudur \\ email : fransiscadian79@gmail.com
}

\begin{abstract}
Abstak: Upaya pelestarian cagar budaya berdasarkan Undang-Undang Republik Indonesia No. 11 Tahun 2010 tentang Cagar Budaya meliputi pelindungan, pengembangan dan pemanfaatan. Suatu warisan budaya yang telah ditetapkan sebagai cagar budaya secara hukum terikat dengan aturan ataupun kaidah yang ada di dalam undang-undang ini. Segala bentuk kegiatan pelestarian cagar budaya baik upaya pelindungan, pengembangan dan pemanfaatan harus didahului dengan izin dari instansi yang berwenang dibidang pelestarian. Setiap orang yang melakukan kegaitan pelestaian tanpa izin dari pemerintah sesuai dengan kewenangannya dapat dikenakan sanksi sesuai aturan yang berlaku. Perizinan ini sebenarnya tidak untuk menyulitkan pemilik cagar budaya namun sematamata untuk melindungi cagar budaya agar tidak rusak ataupun salah dalam penanganannya.
\end{abstract}

Kata kunci: pelestarian, perijinan, Undang-Undang No. 11 Tahun 2010

\begin{abstract}
Abstak: Preservation efforts based on National Law Number 11 Year 2010 regarding Cultural Heritage include protection, development, and utilization. When a cultural site has been designated as cultural heritage, it has to oblige with the regulations stated in this national law. Every effort must be preceded by permit that has the authority in cultural heritage preservation. Everyone who performed preservation effort without permit could be sanctioned according to the law. The permit is not to complicate the cultural heritage's owners, but mainly to ensure that the conservation efforts are not damaging the heritage itself.
\end{abstract}

Keywords: permit, national law number 11 year 2010, preservation

\section{Pendahuluan}

Ruang lingkup sebuah pelestarian cagar budaya meliputi kegiatan pelindungan, pengembangan dan pemanfaatan Cagar Budaya di darat dan di air. Seperti definisi yang tercantum dalam Undang-Undang Republik Indonesia Nomor 11 Tahun 2010 tentang Cagar Budaya, pelestarian adalah upaya dinamis untuk mempertahankan keberadaan cagar budaya dan nilainya dengan cara melindungi, mengembangkan, dan memanfaatkannya.

Jika kita melihat definisi dari masing-masing unsur pelestarian, pertama yaitu pelindungan adalah upaya mencegah dan menanggulangi dari kerusakan, kehancuran, atau kemusnahan dengan cara Penyelamatan, Pengamanan, Zonasi, Pemeliharaan, dan Pemugaran Cagar Budaya. Kedua, pengembangan adalah peningkatan potensi nilai, informasi, dan promosi cagar budaya serta pemanfaatannya melalui Penelitian, Revitalisasi, dan Adaptasi secara berkelanjutan serta tidak bertentangan dengan tujuan Pelestarian. Ketiga, pemanfaatan adalah pendayagunaan Cagar Budaya untuk kepentingan sebesar-besarnya kesejahteraan rakyat dengan tetap mempertahankan kelestariannya (UU RI No. 11 Tahun
2010).

Upaya pelestarian cagar budaya dalam dasar pertimbangan dikeluarkannya UU RI Nomor 11 Tahun 2010 tentang Cagar Budaya dijelaskan bahwa cagar budaya merupakan kekayaan budaya bangsa sebagai wujud pemikiran dan perilaku kehidupan manusia yang penting artinya bagi pemahaman dan pengembangan sejarah, ilmu pengetahuan, dan kebudayaan dalam kehidupan bermasyarakat, berbangsa, dan bernegara sehingga perlu dilestarikan dan dikelola secara tepat melalui upaya pelindungan, pengembangan, dan pemanfaatan dalam rangka memajukan kebudayaan nasional untuk sebesarbesarnya kemakmuran rakyat.

Tulisan ini akan menjabarkan berbagai ketentuan yang berhubungan dengan upaya perizinan pelestarian cagar budaya beserta dengan sanksi-sanksinya menurut Undang-Undang Republik Indonesia Nomor 11 Tahun 2010 tentang Cagar Budaya dan RPP Pelestarian yang masih dalam proses penetapan. Segala bentuk upaya pelestarian harus didahului dengan proses perizinan dari pihak yang berwenang agar cagar budaya tersebut dapat lestari dan terjaga. 


\section{Rumusan Masalah}

Rumusan masalah yang diangkat di dalam tulisan ini adalah perizinan apa saja yang harus dilakukan setiap orang dalam melakukan usaha pelestarian cagar budaya berdasarkan Undang-Undang Republik Indonesia Nomor 11 Tahun 2010 tentang Cagar Budaya.

\section{Macam-Macam Perizinan}

Yang menjadi pokok bahasan dalam tulisan ini adalah perizinan dalam pelestarian cagar budaya meliputi perizinan dalam pelindungan cagar budaya, perizinan dalam pengembangan cagar budaya dan perizinan dalam pemanfaatan cagar budaya berdasarkan Undang-Undang Republik Indonesia Nomor 11 Tahun 2010 tentang Cagar Budaya dan draf RPP Pelestarian Cagar Budaya yang masih dalam proses penetapan.

Sebelum menginjak ke perizinan dalam pelestarian cagar budaya pada bab awal UU No. 11 Tahun 2010 tentang Cagar Budaya ada hal penting yang berkaitan dengan perizinan yaitu mengenai bab pemilikan dan penguasaan serta bab penemuan dan pencarian. Pada bab pemilikan dan penguasaan diatur bahwa setiap orang dilarang mengalihkan kepemilikan Cagar Budaya kecuali dengan izin pihak yang terkait sesuai dengan kewenangannya seperti yang dinyatakan dalam Pasal 17 UU RI No. 11 Tahun 2010.

Pengalihan kepemilkan cagar budaya ini selanjutnya dijelaskan dalam draf Pelestarian Cagar Budaya Pasal 3 dan 4. Pada Pasal 4 draf RPP Pelestarian secara khusus dijelaskan mengenai permohonan ijin pengalihan kepemilikan cagar budaya beserta persyaratannya. Terdapat sanksi pidana bagi orang yang melakukan pengalihan kepemilikan cagar budaya tanpa izin, yaitu pada Pasal 101 UU CB No. 11 Tahun 2010.

Pada bab penemuan dan pencarian dalam Undang-Undang Republik Indonesia Nomor 11 Tahun 2010 tentang Cagar Budaya dimulai Pasal 23 yang menerangkan tentang Penemuan. Dalam hal penemuan ini setiap orang yang menemukan yang diduga cagar

Pasal 17

(1) Setiap orang dilarang mengalihkan kepemilikan Cagar Budaya peringkat nasional, peringkat provinsi, atau peringkat kabupaten/kota, baik seluruh maupun bagian-bagiannya, kecuali dengan izin Menteri, gubernur, atau bupati/wali kota sesuai dengan tingkatannya.

(2) Ketentuan lebih lanjut mengenai pemberian izin sebagaimana dimaksud pada ayat (1) diatur dalam Peraturan Pemerintah.

\section{Draf RPP Pelestarian Cagar Budaya}

Pasal 3

(1) Pengambilalihan Kepemilikan Cagar Budaya oleh Negara dapat dilakukan apabila pemilik Cagar Budaya: a. meninggal dunia:

1) tidak mempunyai ahli waris; atau

2) tidak menyerahkannya kepada orang lain berdasarkan wasiat, hibah, atau hadiah. b. Warga Negara Asing yang meninggalkan Indonesia selama 5 (lima) tahun berturut-turut tanpa mengalihkan Kepemilikan dan penguasaan kepada Setiap Orang dan/atau Masyarakat Hukum Adat;

c. badan hukum asing yang tidak beroperasi lagi di Indonesia tanpa mengalihkan kepemilikan dan penguasaan kepada Setiap Orang dan/atau Masyarakat Hukum Adat;

d. tidak dapat membuktikan sahnya Kepemilikan Cagar Budaya;

e. memperoleh Cagar Budaya secara tidak sah;

f. tidak diketahui; dan/atau

g. memiliki Cagar Budaya yang sangat langka jenisnya, unik rancangannya, dan sedikit jumlahnya di Indonesia

(2) Pengambilalihan Kepemilikan oleh Negara sebagaimana dimaksud pada ayat (1) dilakukan oleh Menteri, gubernur, atau bupati/wali kota sesuai dengan peringkatnya.

(3) Pengambilalihan Kepemilikan oleh Negara sebagaimana dimaksud pada ayat (1) dan ayat (2) dilakukan dengan memberitahukan kepada pemilik dan/atau yang menguasai Cagar Budaya dan diumumkan secara terbuka.

\section{Pasal 4}

(1) Pengalihan kepemilikan Cagar Budaya diajukan dengan permohonan izin kepada Menteri, gubernur, atau bupati/wali kota sesuai dengan kewenangannya.

(2) Permohonan izin sebagaimana dimaksud pada ayat (1) dilengkapi dengan surat keterangan status dan Kepemilikan Cagar Budaya.

(3) Selain surat keterangan status dan Kepemilikan Cagar Budaya sebagaimana dimaksud pada ayat (2), permohonan izin harus melampirkan:

a. surat keterangan ahli waris untuk yang diwariskan;

b. surat pernyataan hibah untuk yang dihibahkan;

c. surat perjanjian tukar menukar untuk yang ditukarkan;

d. surat pernyataan dari pemberi hadiah untuk yang dihadiahkan;

e. surat perjanjian jual-beli untuk yang dijual;

f. surat berita acara pemberian ganti kerugian untuk yang diganti rugi; atau

g. penetapan atau keputusan pengadilan untuk yang ditetapkan atau diputuskan oleh pengadilan.

(4) Gubernur, atau bupati/wali kota dalam memberikan izin sebagaimana dimaksud pada ayat (3), harus memperoleh rekomendasi terlebih dahulu dari Unit Pelaksana Teknis. 
(5) Pengalihan Kepemilikan sebagaimana dimaksud pada ayat (2) ditindaklanjuti dengan surat perubahan status Kepemilikan Cagar Budaya dan perubahan nama pemilik dalam register nasional.

(6) Dalam hal pemilik Cagar Budaya yang baru tidak mengajukan permohonan perubahan Kepemilikan, maka tidak berhak mendapatkan Insentif dari Pemerintah atau Pemerintah Daerah sesuai peraturan yang berlaku.

\section{Ketentuan pidana berdasar UU RI No. 11 Tahun 2010 tentang Cagar Budaya}

\section{Pasal 101}

Setiap orang yang tanpa izin mengalihkan kepemilikan Cagar Budaya sebagaimana dimaksud dalam Pasal 17 ayat (1) dipidana dengan pidana penjara paling singkat 3 (tiga) bulan dan paling lama 5 (lima) tahun dan/atau denda paling sedikit Rp400.000.000,00 (empat ratus juta rupiah) dan paling banyak Rp1.500.000.000,00 (satu miliar lima ratus juta rupiah).

budaya wajib hukumnya untuk lapor kepada instansi yang berwenang di bidang kebudayaan, Kepolisian Negara Republik Indonesia, atau instansi terkait paling lama 30 (tiga puluh hari) sejak ditemukan. Apabila dengan sengaja tidak melapor maka ada konsekuensi hukumnya terkena Pasal 102, dipidana penjara paling lama 5 (lima) tahun dan/atau denda paling banyak Rp 500.000.000,00 (lima ratus juta rupiah). Perihal penemuan cagar budaya ini tidak berkaitan dengan kegiatan yang memerlukan izin.

Perihal Pencarian dimulai Pasal 26 UU RI No. 11

Tahun 2010, kegiatan pencarian obyek yang diduga cagar budaya wajib dilakukan oleh pemerintah. Setiap orang atau masyarakat Hukum Adat melakukan pencarian objek yang diduga cagar budaya dengan izin Pemerintah sesuai dengan kewenangannya dan kegiatan pencarian ini harus dilakukan melalui kegiatan penelitian, seperti yang dijelaskan dalam Pasal 11 draf RPP Pelestarian Cagar Budaya. Permohonan izin dan persyaratannya dijabarkan dalam Pasal 12.

Bagi orang yang melakukan pencarian objek yang diduga cagar budaya tanpa izin dikenakan sanksi hukum sesuai Pasal 103 UU CB No. 11 Tahun 2010.

\section{Pencarian}

Pasal 26

(1) Pemerintah berkewajiban melakukan pencarian benda, bangunan, struktur, dan/atau lokasi yang diduga sebagai Cagar Budaya.

(2) Pencarian Cagar Budaya atau yang diduga Cagar Budaya dapat dilakukan oleh setiap orang dengan penggalian, penyelaman, dan/atau pengangkatan di darat dan/atau di air.

(3) Pencarian sebagaimana dimaksud pada ayat (1) dan ayat (2) hanya dapat dilakukan melalui penelitian dengan tetap memperhatikan hak kepemilikan dan/atau penguasaan lokasi.

(4) Setiap orang dilarang melakukan pencarian Cagar Budaya atau yang diduga Cagar Budaya dengan penggalian, penyelaman, dan/atau pengangkatan di darat dan/atau di air sebagaimana dimaksud pada ayat (2), kecuali dengan izin Pemerintah atau Pemerintah Daerah sesuai dengan kewenangannya.

(5) Ketentuan lebih lanjut mengenai pemberian izin sebagaimana dimaksud pada ayat (4) diatur dalam Peraturan Pemerintah.

\section{Draf RPP Pelestarian Cagar Budaya}

Pasal 11

(1) Setiap Orang dan/atau Masyarakat Hukum Adat dapat melakukan pencarian Cagar Budaya dan/atau Objek yang Diduga Cagar Budaya.

(2) Dalam melaksanakan pencarian Cagar Budaya dan/atau Objek yang Diduga Cagar Budaya yang dilakukan oleh Setiap Orang dan/atau Masyarakat Hukum Adat sebagaimana dimaksud pada ayat (1) harus:

a. bekerjasama dengan instansi Pemerintah yang berwenang;

b. melalui Penelitian dengan penggalian, penyelaman, dan/atau pengangkatan, baik Di Darat dan/atau Di Air;

c. memperoleh izin dari Pemerintah atau Pemerintah Daerah sesuai dengan kewenangannya;

d. tetap memperhatikan hak kepemilikan dan/atau penguasaan lokasi; dan

e. memperhatikan keseimbangan aspek ideologis, akademis, ekologis, dan ekonomis guna meningkatkan kesejahteraan rakyat.

Pasal 12

(1) Kegiatan pencarian Di Darat dilaksanakan setelah memperoleh izin dari bupati/wali kota, dengan tembusan kepada:

a. Menteri;

b. gubernur;

c. instansi terkait; dan

d. pemilik dan/atau yang menguasai lokasi penelitian.

(2) Penelitian sebagaimana dimaksud pada Pasal 11 ayat (2) huruf b yang dilakukan terhadap Objek yang Diduga Cagar Budaya dan/atau Cagar Budaya yang dimiliki/dikuasai sendiri tidak memerlukan izin.

(3) Pengajuan permohonan izin terhadap pencarian melalui penelitian yang dilakukan Di Air diajukan kepada:

a. Menteri;

b. gubernur; atau

c. bupati/wali kota;

sesuai dengan kewenangannya berdasarkan peraturan perundang-undangan.

(4) Permohonan izin sebagaimana dimaksud pada ayat (1) dan ayat (3) harus dilampiri dengan proposal yang 
memuat:

a. identitas pemohon;

b. maksud dan tujuan pencarian;

c. metode dan teknik pencarian;

d. lokasi pencarian;

e. tenggang waktu pencarian;

f. tenaga yang memiliki kompetensi;

g. peralatan yang memadai; dan

h. pembiayaan.

(5) Lokasi pencarian sebagaimana dimaksud pada ayat (4) huruf d untuk pencarian melalui penelitian yang dilakukan Di Air wajib dilengkapi dengan izin lokasi dari instansi pemerintah yang berwenang di bidang kelautan dan perikanan.

(6) Setiap Orang yang berasal dari lembaga yang akan melakukan pencarian, untuk memperoleh izin sebagaimana dimaksud pada ayat (1) dan ayat (3) harus dilengkapi dengan surat tugas dari pimpinan lembaga.

(7) Sebelum izin diberikan oleh Menteri, gubernur, bupati/walikota harus memperoleh rekomendasi terlebih dahulu dari Unit Pelaksana Teknis.

\section{Ketentuan pidana berdasar UU RI No. 11 Tahun 2010 tentang Cagar Budaya}

Pasal 103

Setiap orang yang tanpa izin Pemerintah atau Pemerintah Daerah melakukan pencarian Cagar Budaya sebagaimana dimaksud dalam Pasal 26 ayat (4) dipidana dengan pidana penjara paling singkat 3 (tiga) bulan dan paling lama 10 (sepuluh) tahun dan/atau denda paling sedikit Rp150.000.000,00 (seratus lima puluh juta rupiah) dan paling banyak Rp1.000.000.000,00 (satu miliar rupiah).

\section{A. Pelindungan}

Telah disebutkan bahwa upaya pelindungan meliputi Penyelamatan, Pengamanan, Zonasi, Pemeliharaan, dan Pemugaran Cagar Budaya. Kita lihat masing-masing definisinya.

Penyelamatan, adalah upaya menghindarkan dan/atau menanggulangi Cagar Budaya dari kerusakan, kehancuran, atau kemusnahan.

Pengamanan, adalah upaya untuk menjaga dan mencegah Cagar Budaya dari ancaman dan/atau gangguan.

Zonasi, adalah penentuan batas-batas keruangan Situs Cagar Budaya dan Kawasan Cagar Budaya sesuai dengan kebutuhan.

Pemeliharaan, adalah upaya menjaga dan merawat agar kondisi fisik Cagar Budaya tetap lestari.

Pemugaran, adalah upaya pengembalian kondisi fisik Benda Cagar Budaya, Bangunan Cagar Budaya, dan Struktur Cagar Budaya yang rusak sesuai dengan keaslian bahan, bentuk, tata letak, dan/atau teknik pengerjaan untuk memperpanjang usianya.
Dalam Undang-Undang Republik Indonesia Nomor 11 Tahun 2010 tentang Cagar Budaya, kegiatan pelindungan yang membutuhkan perizinan adalah kegiatan pengamanan. Kegiatan penyelamatan cagar budaya dilakukan dengan tujuan untuk mencegah kerusakan karena faktor manusia dan/atau alam yang mengakibatkan berubahnya keaslian dan nilai-nilai yang menyertainya serta mencegah pemindahan dan beralihnya pemilikan dan/atau penguasaan cagar budaya yang bertentangan dengan ketentuan perundang-undangan.

Berdasarkan Pasal 81 draf RPP Pelestarian Cagar Budaya, kegiatan penyelamatan cagar budaya harus didahului dengan kajian dan dilakukan oleh Tenaga Ahli Pelestarian, serta mempertahankan nilai penting cagar budaya/objek yang diduga cagar budaya.

Kegiatan pengamanan cagar budaya dilakukan untuk menjaga dan mencegah cagar budaya agar tidak hilang, rusak, hancur, atau musnah. Kegiatan pengamanan ini merupakan kewajiban bagi pemilik atau yang menguasai cagar budaya. Pada Pasal 66 UU RI

\section{Draf RPP Pelestarian Cagar Budaya}

(3) Penyelamatan Cagar Budaya dan/atau Objek yang Diduga Cagar Budaya dalam keadaan biasa karena dampak kegiatan pembangunan harus dilakukan melalui kegiatan terencana dengan:

a. didahului kajian;

b. dilakukan oleh Tenaga Ahli Pelestarian; dan

c. mempertahankan nilai penting Cagar Budaya dan/atau Objek yang Diduga Cagar Budaya.

(4) Penyelamatan Cagar Budaya dan/atau Objek yang Diduga Cagar Budaya sebagaimana dimaksud pada ayat (1) dan ayat (2), dilakukan oleh Unit Pelaksana Teknis dan/atau instansi Pemerintah Daerah yang berwenang di bidang Pelestarian Cagar Budaya.

(5) Setiap Orang dan/atau Masyarakat Hukum Adat yang memiliki, menguasai, atau mengelolanya dapat melakukan Penyelamatan sebagaimana dimaksud pada ayat (1) dan ayat (2) dengan Unit Pelaksana Teknis dan/atau instansi Pemerintah Daerah yang berwenang di bidang Pelestarian Cagar Budaya. 
Nomor 11 Tahun 2010 tentang Cagar Budaya dinyatakan bahwa setiap orang dilarang merusak dan mencuri cagar budaya, baik seluruh maupun bagian-bagiannya, dari kesatuan, kelompok, dan/atau dari letak asal. Apabila pasal ini dilanggar akan dikenakan sanksi hukum seperti yang tercantum pada Pasal 105 dan 106.

Dalam kegiatan pengamanan ini setiap orang dilarang memindahkan dan memisahkan cagar budaya kecuali dengan izin kepada Pemerintah sesuai dengan tingkatan kewenangannya, hal ini diatur dalam Pasal 67 UU RI Nomor 11 Tahun 2010 tentang Cagar Budaya. Pelanggaran pada pasal ini akan diberikan sanksi pidana sesuai dengan Pasal 107 dan Pasal 108. Selain itu setiap orang juga dilarang membawa cagar budaya ke luar negeri tanpa izin. Bagi yang melanggar Pasal ini dikenakan sanksi hukum sesuai dengan Pasal 109.

Dalam draf RPP Pelestarian Cagar Budaya Pasal 101 dijelaskan mengenai permohonan izin apabila pemilik akan mengalihkan kepemilikan, memindahkan, memisahkan, mengubah fungsi dan/atau melakukan perbanyakan cagar budaya serta akan membawa cagar budaya keluar wilayah kabupaten/kota serta keluar wilayah Indonesia. Pemberian izin oleh Pemerintah sesuai dengan kewenangannya juga harus berdasarkan rekomendasi dari Unit Pelaksana Teknis.

Kegiatan Pelindungan cagar budaya yang

Pasal 67

(1) Setiap orang dilarang memindahkan Cagar Budaya peringkat nasional, peringkat provinsi, atau peringkat kabupaten/kota, baik seluruh maupun bagian-bagiannya, kecuali dengan izin Menteri, gubernur, atau bupati/ wali kota sesuai dengan tingkatannya.

(2) Setiap orang dilarang memisahkan Cagar Budaya peringkat nasional, peringkat provinsi, atau peringkat kabupaten/kota, baik seluruh maupun bagian-bagiannya, kecuali dengan izin Menteri, gubernur, atau bupati/ wali kota sesuai dengan tingkatannya.

(3) Ketentuan lebih lanjut mengenai pemberian izin sebagaimana dimaksud pada ayat (1) dan ayat (2) diatur dalam Peraturan Pemerintah.

Pasal 68

(1) Cagar Budaya, baik seluruh maupun bagian-bagiannya, hanya dapat dibawa ke luar wilayah Negara Kesatuan Republik Indonesia untuk kepentingan penelitian, promosi kebudayaan, dan/atau pameran.

(2) Setiap orang dilarang membawa Cagar Budaya sebagaimana dimaksud pada ayat (1), kecuali dengan izin Menteri.

Pasal 69

(1) Cagar Budaya, baik seluruh maupun bagian-bagiannya, hanya dapat dibawa ke luar wilayah provinsi atau kabupaten/kota untuk kepentingan penelitian, promosi kebudayaan, dan/atau pameran.

(2) Setiap orang dilarang membawa Cagar Budaya sebagaimana dimaksud pada ayat (1), kecuali dengan izin gubernur atau bupati/wali kota sesuai dengan kewenangannya.

Pasal 70

Ketentuan lebih lanjut mengenai pemberian izin sebagaimana dimaksud dalam Pasal 68 dan Pasal 69 diatur dalam Peraturan Pemerintah.

\section{Draf RPP Pelestarian Cagar Budaya}

\section{Pasal 101}

(1) Pemilik dan/atau yang menguasai benda, bangunan, dan/atau struktur Cagar Budaya atau yang diduga Cagar Budaya dapat:

a. mengalihkan Kepemilikan;

b. memindahkan;

c. memisahkan;

d. mengubah fungsi; dan/atau

e. melakukan Perbanyakan,

setelah memperoleh izin Menteri, gubernur, atau bupati/wali kota sesuai dengan kewenangannya setelah memperoleh rekomendasi terlebih dahulu dari Unit Pelaksana Teknis.

(2) Dalam hal benda, bangunan, dan/atau struktur Cagar Budaya atau yang diduga Cagar Budaya dibawa ke luar wilayah Indonesia, ke luar wilayah provinsi, ke luar wilayah kabupaten/kota harus memperoleh izin Menteri, gubernur, atau bupati/wali kota sesuai dengan kewenangannya setelah memperoleh rekomendasi terlebih dahulu dari Unit Pelaksana Teknis.

(3) Izin sebagaimana dimaksud pada ayat (1) diberikan dengan syarat-syarat:

a. diajukan oleh pemilik dan/atau yang menguasai dengan surat permohonan yang memuat:

1) identitas pemohon;

2) identitas Cagar Budaya; dan

3) maksud dan tujuan.

dan

b. melampirkan proposal apabila bertujuan untuk kegiatan.

(4) Membawa ke luar wilayah Indonesia sebagaimana dimaksud pada ayat (1):

a. hanya dapat dilakukan untuk kepentingan penelitian, promosi kebudayaan, dan/atau pameran;

b. sedapat mungkin diasuransikan; dan

c. melampirkan sistem Pengamanan untuk memindahkan dan/atau memisahkan. 
(5) Izin sebagaimana dimaksud pada ayat (1) diberikan dengan syarat-syarat:

a. diajukan oleh pemilik dan/atau yang menguasai dengan surat permohonan yang memuat:

1) identitas pemohon;

2) identitas Cagar Budaya; dan

3) maksud dan tujuan.

dan

b. melampirkan proposal apabila bertujuan untuk kegiatan.

(6) Izin sebagaimana dimaksud pada ayat (1) dan ayat (3) diajukan kepada Menteri, gubernur, atau bupati/wali kota sesuai dengan kewenangannya.

(7) Gubernur, atau bupati/wali kota dalam memberikan izin sebagaimana dimaksud pada ayat (4), harus memperoleh rekomendasi terlebih dahulu dari Unit Pelaksana Teknis.

\section{Ketentuan pidana berdasar UU RI No. 11 Tahun 2010 tentang Cagar Budaya}

\section{Pasal 107}

Setiap orang yang tanpa izin Menteri, gubernur, atau bupati/wali kota, memindahkan Cagar Budaya sebagaimana dimaksud dalam Pasal 67 ayat (1) dipidana dengan pidana penjara paling singkat 3 (tiga) bulan dan paling lama 2 (dua) tahun dan/atau denda paling sedikit Rp100.000.000,00 (seratus juta rupiah) dan paling banyak Rp1.000.000.000,00 (satu miliar rupiah).

\section{Pasal 108}

Setiap orang yang tanpa izin Menteri, gubernur atau bupati/wali kota, memisahkan Cagar Budaya sebagaimana dimaksud dalam Pasal 67 ayat (2) dipidana dengan pidana penjara paling lama 10 (sepuluh) tahun dan/atau denda paling sedikit Rp100.000.000,00 (seratus juta rupiah) dan paling banyak Rp2.500.000.000,00 (dua miliar lima ratus juta rupiah).

\section{Pasal 109}

(1) Setiap orang yang tanpa izin Menteri, membawa Cagar Budaya ke luar wilayah Negara Kesatuan Republik Indonesia sebagaimana dimaksud dalam Pasal 68 ayat (2) dipidana dengan pidana penjara paling singkat 6 (enam) bulan dan paling lama 10 (sepuluh) tahun dan/atau denda paling sedikit Rp200.000.000,00 (dua ratus juta rupiah) dan paling banyak Rp1.500.000.000,00 (satu miliar lima ratus juta rupiah).

(2) Setiap orang yang tanpa izin gubernur atau izin bupati/wali kota, membawa Cagar Budaya ke luar wilayah provinsi atau kabupaten/kota sebagaimana dimaksud dalam Pasal 69 ayat (2) dipidana dengan pidana penjara paling lama 5 (lima) tahun dan/atau denda paling sedikit Rp1.000.000,00 (satu juta rupiah) dan paling banyak Rp100.000.000,00 (seratus juta rupiah).

memerlukan perizinan adalah kegiatan pemugaran. Pasal 77 UU RI No.11 Tahun 2010 tentang Cagar Budaya menjelaskan tentang kegiatan pemugaran yang dilakukan pada bangunan dan struktur cagar budaya yang rusak dengan tujuan untuk mengembalikan kondisi fisik dengan cara memperbaiki, memperkuat, dan/ atau mengawetkannya melalui pekerjaan rekonstruksi, konsolidasi, rehabilitasi, dan restorasi.

Pasal 77

(5) Pemugaran Bangunan Cagar Budaya dan Struktur Cagar Budaya wajib memperoleh izin Pemerintah atau Pemerintah Daerah sesuai dengan kewenangannya.

(6) Ketentuan lebih lanjut mengenai Pemugaran Cagar Budaya diatur dalam Peraturan Pemerintah.

\section{Draf RPP Pelestarian Cagar Budaya}

\section{Pasal 118}

(1) Unit Pelaksana Teknis atau instansi Pemerintah Daerah yang berwenang di bidang Pelestarian Cagar Budaya melakukan Pemugaran Bangunan Cagar Budaya dan/atau Struktur Cagar Budaya sesuai dengan peringkat Cagar Budaya.

(2) Pemilik dan/atau yang menguasai Bangunan Cagar Budaya dan/atau Struktur Cagar Budaya dapat melakukan Pemugaran didasarkan izin dengan syarat:

a. mengajukan surat permohonan izin Pemugaran yang memuat:

1) identitas pemohon;

2) identitas Bangunan Cagar Budaya dan/atau Struktur Cagar Budaya yang akan dipugar; dan

3) waktu dan lokasi Pemugaran.

b. melampirkan foto kopi surat Penetapan Cagar Budaya yang dilegalisir;

c. melampirkan foto kopi Surat Keterangan Kepemilikan Cagar Budaya yang dilegalisir;

d. dokumen studi kelayakan untuk dapat dipugar;

e. rencana studi teknis dan rencana Pemugaran;

f. menginformasikan Tenaga Ahli Pelestarian yang akan menjadi konsultan;

g. izin lingkungan; dan

h. surat keterangan pendanaan;

i. izin mendirikan bangunan yang dikeluarkan oleh Pemerintah Daerah.

(3) Permohonan izin Pemugaran sebagaimana dimaksud pada ayat (2) diajukan kepada Menteri, gubernur, atau bupati/wali kota sesuai dengan kewenangannya.

(4) Gubernur, atau bupati/wali kota dalam memberikan izin sebagaimana dimaksud pada ayat (3), harus memperoleh kajian teknis terlebih dahulu dari Unit Pelaksana Teknis.

(5) Pemilik dan/atau yang menguasai Bangunan Cagar Budaya dan/atau Struktur Cagar Budaya dalam melakukan 
Pemugaran sebagaimana dimaksud pada ayat (2) didampingi oleh Unit Pelaksana Teknis dan/atau instansi Pemerintah Daerah yang berwenang di bidang Pelestarian Cagar Budaya dalam bentuk konsultasi.

Pasal 128

Pemerintah, Pemerintah Daerah, Setiap Orang, dan/atau Masyarakat Hukum Adat dilarang melakukan Pemugaran dengan membuat bangunan baru dan/atau struktur baru yang menggunakan keseluruhan dan/atau bagian-bagian Bangunan Cagar Budaya dan/atau Struktur Cagar Budaya yang ada.

Kegiatan pemugaran cagar budaya harus memperhatikan beberapa hal diantaranya (a). keaslian bahan, bentuk, tata letak, gaya, dan/atau teknologi pengerjaan; (b). kondisi semula dengan tingkat perubahan sekecil mungkin; (c). penggunaan teknik, metode, dan bahan yang tidak bersifat merusak; dan (d). kompetensi pelaksana di bidang pemugaran.

Sebelum kegiatan pemugaran dimulai, pemilik atau yang menguasai cagar budaya terlebih dahulu harus mengajukan permohonan izin kepada pemerintah sesuai dengan kewenangannya. Syarat permohonan izin seperti yang tercantum dalam Pasal 118 draf RPP Pelestarian Cagar Budaya. Dalam kegiatan pemugaran cagar budaya pemilik atau yang menguasai cagar budaya didampingi oleh Unit Pelaksana Teknis atau instansi Pemerintah Daerah yang berwenang dibidang pelestarian. Gubernur atau bupati/walikota dalam memberikan izin pemugaran harus memperoleh kajian teknis dari Unit Pelaksana Teknis. Pelanggaran dalam hal pemugaran ini belum diatur dalam Undang-Undang.

B. Pengembangan

Upaya pengembangan cagar budaya dapat dilakukan melalui kegiatan Penelitian, Revitalisasi, dan Adaptasi. Definisi dari masing-masing kegiatan adalah:

Penelitian adalah kegiatan ilmiah yang dilakukan menurut kaidah dan metode yang sistematis untuk memperoleh informasi, data, dan keterangan bagi kepentingan Pelestarian Cagar Budaya, ilmu pengetahuan, dan pengembangan kebudayaan.
Revitalisasi adalah kegiatan pengembangan yang ditujukan untuk menumbuhkan kembali nilai-nilai penting Cagar Budaya dengan penyesuaian fungsi ruang baru yang tidak bertentangan dengan prinsip pelestarian dan nilai budaya masyarakat.

Adaptasi adalah upaya pengembangan Cagar Budaya untuk kegiatan yang lebih sesuai dengan kebutuhan masa kini dengan melakukan perubahan terbatas yang tidak akan mengakibatkan kemerosotan nilai pentingnya atau kerusakan pada bagian yang mempunyai nilai penting.

Pengembangan cagar budaya dilakukan dengan memperhatikan prinsip kemanfaatan, keamanan, keterawatan, keaslian, dan nilai-nilai yang melekat padanya. Menurut Pasal 78 UU RI No. 11 Tahun 2010 tentang Cagar Budaya, setiap orang dapat melakukan pengembangan cagar budaya setelah mendapatkan izin dari Pemerintah dan pemilik atau yang menguasai cagar budaya.

Kegiatan penelitian dilakukan pada setiap rencana pengembangan cagar budaya untuk menghimpun informasi serta mengungkap, memperdalam, dan menjelaskan nilai-nilai budaya (Pasal 79 UU RI No. 11 Tahun 2010 tentang Cagar Budaya). Dalam pasal 132 draf RPP Pelestarian Cagar Budaya dijelaskan bahwa kegiatan penelitian cagar budaya harus didahului dengan izin Menteri, gubernur dan bupati/wali kota sesuai dengan kewenangannya. Persyaratan permohonan izin dirinci pada Pasal 132 ayat (5).

\footnotetext{
(2) Setiap orang dapat melakukan Pengembangan Cagar Budaya setelah memperoleh: a. izin Pemerintah atau Pemerintah Daerah; dan

(1) Penelitian dalam rangka Pengembangan Cagar Budaya bertujuan untuk menghimpun informasi serta mengungkap, memperdalam, dan menjelaskan nilai-nilai budaya.

(2) Penelitian sebagaimana dimaksud pada ayat (1) dapat dilakukan oleh: a. instansi Pemerintah yang berwenang di bidang Penelitian arkeologi; b. Instansi Pemerintah yang Berwenang di Bidang Pelestarian Cagar Budaya; c. Instansi Pemerintah Daerah yang berwenang di bidang Pelestarian Cagar Budaya; d. instansi Pemerintah dan/atau Pemerintah Daerah lainnya; dan/atau e. Setiap Orang dan/atau Masyarakat Hukum Adat.

(3) Penelitian sebagaimana dimaksud pada ayat (2) dapat dilakukan terhadap Cagar Budaya milik dan/atau yang dikuasai oleh: a. Setiap Orang dan/atau Masyarakat hukum Adat;
} 


\section{b. Pemerintah; dan/atau}

c. Pemerintah Daerah.

(4) Penelitian sebagaimana dimaksud pada ayat (2) didasarkan izin dari Menteri, gubernur, bupati/wali kota sesuai dengan kewenangannya.

(5) Permohonan izin sebagaimana dimaksud pada ayat (4) disertai syarat:

a. mengajukan surat permohonan yang memuat:

1) identitas peneliti;

2) Cagar Budaya yang akan diteliti;

3) jenis Penelitian;

4) metode penelitian;

5) tujuan Penelitian;

6) jangka waktu Penelitian; dan

7) lokasi Penelitian.

b. melampirkan proposal Penelitian;

c. pernyataan kesanggupan menyerahkan laporan Penelitian dan mempublikasikan hasil Penelitian; dan

d. menyerahkan laporan Penelitian dan bukti publikasi hasil Penelitian apabila sebelumnya pernah melakukan Penelitian.

(6) Menteri, gubernur, atau bupati/wali kota sesuai dengan kewenangannya memeriksa dan mempertimbangkan:

a. kelengkapan syarat sebagaimana dimaksud pada ayat (2);

b. prinsip keamanan, kemanfaatan, keterawatan, keaslian, serta nilai-nilai yang melekat pada Cagar Budaya;

c. kemanfaatan hasil Penelitian bagi Pengembangan Cagar Budaya; dan

d. dipenuhinya kewajiban publikasi laporan hasil Penelitian yang sudah dilakukan pada masa sebelumnya.

Setiap orang atau Masyarakat Hukum Adat dapat melakukan revitalisasi didasarkan dengan izin kepada Pemerintah sesuai dengan kewenangannya. Kegiatan revitalisasi diatur dalam Pasal 80-82 UU RI No. 11 Tahun 2010 tentang Cagar Budaya. Keterangan lebih rinci diatur dalam draf RPP Pelestarian Cagar Budaya Pasal 135. Permohonan izin revitalisasi cagar budaya dijelaskan dalam Pasal 135 ayat (3). Gubernur atau bupati/wali kota sesuai dengan kewenangannya dapat melimpahkan wewenangnya kepada instansi Pemerintah Daerah yang berwenang dalam bidang Pelestarian Cagar Budaya (Pasal 135 ayat (4). Dalam hal ini kewenangan Gubernur atau bupati/wali kota dapat dilimpahkan kepada Dinas Kebudayaan Propinsi maupun Kabupaten. Sedangkan Menteri dapat melimpahkan wewenangnya kepada Unit Pelaksana Teknis bidang kebudayaan di daerah. Izin yang diberikan dapat dicabut apabila pelaksanaan revitalisasi melanggar prinsip-prinsip pelestarian cagar budaya.

Dalam Pasal 81 UU RINo. 11 Tahun 2010 tentang Cagar Budaya diterangkan bahwa setiap orang dilarang untuk mengubah fungsi ruang Situs atau Kawasan Cagar Budaya kecuali dengan izin Pemerintah sesuai dengan kewenangannya. Konsekuensi hukum apabila pasal ini dilanggar adalah seperti yang diatur dalam Pasal 110.

\section{Pasal 81}

(1) Setiap orang dilarang mengubah fungsi ruang Situs Cagar Budaya dan/atau Kawasan Cagar Budaya peringkat nasional, peringkat provinsi, atau peringkat kabupaten/kota, baik seluruh maupun bagian-bagiannya, kecuali dengan izin Menteri, gubernur, atau bupati/wali kota sesuai dengan tingkatannya.

(2) Ketentuan lebih lanjut mengenai pemberian izin sebagaimana dimaksud pada ayat (1) diatur dalam Peraturan Pemerintah.

\section{Draf RPP Pelestarian Cagar Budaya}

Pasal 135

(1) Revitalisasi dilakukan terhadap Situs Cagar Budaya dan Kawasan Cagar Budaya, dengan melakukan kegiatan yang berupa:

a. menata kembali fungsi ruang;

b. menumbuhkan kembali nilai budaya; dan

c. menguatkan informasi tentang Cagar Budaya.

(2) Revitalisasi sebagaimana dimaksud pada ayat (1) wajib dilakukan oleh Instansi yang Berwenang di Bidang Pelestarian Cagar Budaya.

(3) Setiap Orang dan/atau Masyarakat Hukum Adat dapat melakukan Revitalisasi sebagaimana dimaksud pada ayat (1).

Pasal 136

(1) Setiap Orang dan/atau Masyarakat Hukum Adat yang akan melakukan Revitalisasi sebagaimana dimaksud dalam Pasal 135 ayat (3) didasarkan izin.

(2) Permohonan izin sebagaimana dimaksud pada ayat (1) diajukan kepada Menteri, gubernur, atau bupati/wali kota sesuai dengan kewenangannya.

(3) Permohonan izin sebagaimana dimaksud pada ayat (2) dengan syarat:

a. mengajukan surat permohonan yang berisi identitas pemohon, identitas Situs Cagar Budaya dan/atau Kawasan Cagar Budaya, jenis kegiatan, tujuan, jangka waktu, dan lokasi;

b. melampirkan izin pemilik dan/atau yang menguasai Situs Cagar Budaya dan/atau Kawasan Cagar Budaya bagi pemohon yang bukan pemilik dan/atau yang menguasai;

c. melampirkan rencana induk (master plan) kegiatan Revitalisasi;

d. melampirkan hasil kajian teknis dari Unit Pelaksana Teknis; 
e. melampirkan izin mengubah fungsi ruang situs Cagar Budaya dan/atau kawasan Cagar Budaya;

f. melampirkan perjanjian kerja sama tentang pemanfaatan hasil Revitalisasi antara pemilik dan/atau yang menguasai Situs Cagar Budaya dan/atau Kawasan Cagar Budaya, dengan pengelola;

g. melampirkan dokumen Rencana Tata Bangunan dan Lingkungan; dan

h. izin mendirikan bangunan yang dikeluarkan oleh Pemerintah Daerah.

(4) Gubernur, atau bupati/wali kota sesuai dengan kewenangannya sebagaimana dimaksud pada ayat (2) dapat melimpahkan kewenangan kepada instansi Pemerintah Daerah yang berwenang di bidang Pelestarian Cagar Budaya.

(5) Izin sebagaimana dimaksud pada ayat (3) dan ayat (4) dapat dicabut apabila pelaksanaan kegiatan Revitalisasi tidak sesuai dengan prinsip Pelestarian Cagar Budaya.

Kegiatan adaptasi dalam Undang-Undang Republik Indonesia No. 11 Tahun 2010 tentang Cagar Budaya diatur dalam pasal 83 dan draf RPP Pelestarian Cagar Budaya Pasal 137 dan 138. Kegiatan adaptasi ini sebelum pelaksanaannya juga harus ada izin lebih dulu dari pemerintah sesuai dengan kewenangannya. Persyaratan pengajuan izin kegiatan adaptasi dijelaskan dalam Pasal 138 ayat (3) draf RPP Pelestarian Cagar Budaya.

Seluruh kegiatan Pengembangan Cagar Budaya wajib didokumentasikan seluruh proses kegiatan dan hasilnya, serta dibuat laporan kegiatan dan diserahkan kepada pemberi izin, hal ini sesuai dengan Pasal 139 draf RPP Pelestarian Cagar Budaya.

\section{Pemanfaatan}

Pemanfaatan cagar budaya dalam UU RI No. 11 Tahun 2010 tentang Cagar Budaya dibahas mulai dari Pasal 85 sampai dengan 94. Dalam Pasal 85 dijelaskan bahwa pemerintah, pemerindah daerah, dan setiap orang dapat memanfaatkan cagar budaya untuk kepentingan agama, sosial, pendidikan, ilmu pengetahuan, teknolgi, kebudayaan, dan pariwisata. Diterangkan juga bahwa pemerintah dan pemerintah daerah memfasilitasi pemanfaatan dan promosi cagar budaya tersebut. Wujud dari fasilitasi dapat berupa pemberian izin pemanfaatan, dukungan Tenaga Ahli Pelestarian, dukungan dana, dan pelatihan.

\section{Draf RPP Pelestarian Cagar Budaya}

(1) Adaptasi dapat dilakukan terhadap Bangunan Cagar Budaya dan/atau Struktur Cagar Budaya, dengan melakukan kegiatan yang berupa:

a. mempertahankan nilai-nilai yang melekat;

b. menambah fasilitas sesuai kebutuhan;

c. mengubah susunan ruang secara terbatas; dan/atau

d. mempertahankan gaya arsitektur, konstruksi asli, dan keharmonisan estetika lingkungan di sekitarnya.

(2) Adaptasi sebagaimana dimaksud pada ayat (1) dapat dilakukan oleh Instansi yang Berwenang di Bidang Pelestarian Cagar Budaya, Setiap Orang dan/atau Masyarakat Hukum Adat.

Pasal 138

(1) Setiap Orang dan/atau Masyarakat Hukum Adat yang akan melakukan Adaptasi sebagaimana dimaksud dalam Pasal 137 ayat (2) didasarkan izin.

(2) Permohonan izin sebagaimana dimaksud pada ayat (1) diajukan kepada Menteri, gubernur, atau bupati/wali kota sesuai dengan kewenangannya.

(3) Permohonan izin untuk melakukan Adaptasi sebagaimana dimaksud pada ayat (1) dengan syarat: a. mengajukan surat permohonan berisi identitas pemohon, identitas Bangunan Cagar Budaya dan/atau Struktur Cagar Budaya, jenis kegiatan, tujuan kegiatan, jangka waktu kegiatan, dan lokasi;

b. melampirkan izin dari pemilik dan/atau yang mengusai Bangunan Cagar Budaya dan/atau Struktur Cagar Budaya;

c. melampirkan rencana induk (master plan) kegiatan Adaptasi; dan

d. melampirkan hasil kajian teknis dari Unit Pelaksana Teknis.

(4) Gubernur, atau bupati/wali kota sesuai dengan kewenangannya sebagaimana dimaksud pada ayat (2) dapat melimpahkan kewenangan kepada instansi Pemerintah Daerah yang berwenang di bidang Pelestarian Cagar Budaya.

(5) Izin sebagaimana dimaksud pada ayat (3) dan ayat (4) dapat dicabut apabila pelaksanaan kegiatan Adaptasi tidak sesuai dengan prinsip Pelestarian Cagar Budaya.

\section{Pasal 139}

Setiap orang dan/atau Masyarakat Hukum Adat yang melakukan kegiatan Pengembangan wajib mendokumentasikan proses dan hasil kegiatan Pengembangan dalam bentuk laporan, serta menyerahkannya kepada pemberi izin.

\section{Ketentuan pidana berdasar UU RI No. 11 Tahun 2010 tentang Cagar Budaya}

\section{Pasal 110}

Setiap orang yang tanpa izin Menteri, gubernur, atau bupati/wali kota mengubah fungsi ruang Situs Cagar Budaya dan/atau Kawasan Cagar Budaya sebagaimana dimaksud dalam Pasal 81 ayat (1) dipidana dengan pidana penjara paling lama 5 (lima) tahun dan/atau denda paling sedikit Rp100.000.000,00 (seratus juta rupiah) dan paling banyak Rp1.000.000.000,00 (satu miliar rupiah). 
Pasal 86 UU RI No. 11 Tahun 2010 tentang Cagar Budaya menyebutkan bahwa pemanfaatan cagar budaya yang dapat menyebabkan terjadinya kerusakan wajib didahului dengan kajian, penelitian, dan/atau analisis mengenai dampak lingkungan. Segala bentuk pemanfaatan cagar budaya harus didahului dengan izin kepada Pemerintah sesuai dengan kewenangannya dan masyarakat hukum adat yang menguasai cagar budaya.

Kegiatan pemanfaatan yang diatur dalam UU RI No. 11 Tahun 2010 tentang Cagar Budaya adalah mengenai perbanyakan benda cagar budaya dan pendokumentasian cagar budaya yang kesemuanya harus dengan izin Pemerintah sesuai dengan kewenangannya atau pemilik atau yang menguasainya. Apabila dilanggar maka terdapat sanksi hukum berupa pidana seperti yang tercantum dalam Pasal 111 dan 112.

Di dalam draf RPP Pelestarian Cagar Budaya, kegiatan pemanfaatan untuk kepentingan agama, sosial, pendidikan, ilmu pengetahuan, teknologi, kebudayaan dan pariwisata dijelaskan tersendiri. Pemanfaatan untuk kepentingan agama pada Pasal 143 dan 144, untuk kepentingan sosial pada Pasal 145 dan 146, untuk kepentingan pendidikan pada Pasal 147 dan 148, untuk kepentingan ilmu pengetahuan dan teknologi pada Pasal 149 dan 150, untuk kepentingan kebudayaan pada Pasal 151 dan 152, dan untuk kepentingan pariwisata pada Pasal 153 dan 154.

(1) Cagar Budaya yang pada saat ditemukan sudah tidak berfungsi seperti semula dapat dimanfaatkan untuk kepentingan tertentu.

(2) Pemanfaatan Cagar Budaya sebagaimana dimaksud pada ayat (1) dilakukan dengan izin Pemerintah atau Pemerintah Daerah sesuai dengan peringkat Cagar Budaya dan/atau masyarakat hukum adat yang memiliki dan/atau menguasainya.

Pasal 88

(2) Pemerintah dan/atau Pemerintah Daerah dapat menghentikan pemanfaatan atau membatalkan izin pemanfaatan Cagar Budaya apabila pemilik dan/atau yang menguasai terbukti melakukan perusakan atau menyebabkan rusaknya Cagar Budaya.

\section{Pasal 89}

Pemanfaatan dengan cara perbanyakan Benda Cagar Budaya yang tercatat sebagai peringkat nasional, peringkat provinsi, peringkat kabupaten/kota hanya dapat dilakukan atas izin Menteri, gubernur, atau bupati/wali kota sesuai dengan tingkatannya.

Pasal 92

Setiap orang dilarang mendokumentasikan Cagar Budaya baik seluruh maupun bagian-bagiannya untuk kepentingan komersial tanpa seizin pemilik dan/atau yang menguasainya.

\section{Pasal 93}

(1) Setiap orang dilarang memanfaatkan Cagar Budaya peringkat nasional, peringkat provinsi, atau peringkat kabupaten/kota, baik seluruh maupun bagian-bagiannya, dengan cara perbanyakan, kecuali dengan izin Menteri, gubernur, atau bupati/wali kota sesuai dengan tingkatannya.

(2) Ketentuan lebih lanjut mengenai pemberian izin sebagaimana dimaksud pada ayat (1) diatur dalam Peraturan Pemerintah.

\section{Draf RPP Pelestarian Cagar Budaya}

\section{Pemanfaatan untuk Kepentingan Agama}

Pasal 143

(1) Pemanfaatan Cagar Budaya untuk kepentingan agama sebagaimana dimaksud dalam Pasal 141 ayat (3) dapat dilakukan untuk kegiatan penyelenggaraan perayaan hari besar dan upacara/ritual keagamaan.

(2) Pemanfaatan sebagaimana dimaksud pada ayat (1) dapat dilaksanakan pada semua zona.

(3) Pemanfaatan sebagaimana dimaksud pada ayat (1) tidak dipungut biaya.

\section{Pasal 144}

(1) Pemanfaatan Cagar Budaya untuk kepentingan agama sebagaimana dimaksud dalam Pasal 143 didasarkan izin, kecuali untuk living monument.

(2) Permohonan izin sebagaimana dimaksud pada ayat (1) dengan syarat:

a. mengajukan surat permohonan yang berisi identitas penanggung jawab kegiatan, bentuk perayaan dan upacara, waktu pelaksanaan, dan jumlah peserta; dan b. melampirkan proposal kegiatan.

(3) Jumlah peserta sebagaimana dimaksud pada ayat (2) huruf a harus disesuaikan dengan luas Bangunan Cagar Budaya, Struktur Cagar Budaya, Situs Cagar Budaya, dan Kawasan Cagar Budaya. 


\section{Pemanfaatan untuk Kepentingan Sosial}

\section{Pasal 145}

(1) Pemanfaatan Cagar Budaya untuk kepentingan sosial sebagaimana dimaksud dalam Pasal 141 ayat (3) dapat dilakukan untuk kegiatan sosial kemasyarakatan.

(2) Pemanfaatan sebagaimana dimaksud pada ayat (1) harus tetap memperhatikan dan menghormati nilai yang terkandung dalam Cagar Budaya dan dapat meningkatkan apresiasi masyarakat terhadap Cagar Budaya.

(3) Pemanfaatan sebagaimana dimaksud pada ayat (1) dapat dilaksanakan pada Zona Penyangga, Zona Pengembangan, Zona Pendukung, dan Zona Penunjang.

(4) Pemanfaatan sebagaimana dimaksud pada ayat (1) untuk living monument dapat dilaksanakan pada semua Zona.

Pasal 146

(1) Pemanfaatan Cagar Budaya untuk kegiatan sosial kemasyarakatan sebagaimana dimaksud dalam Pasal 145 didasarkan izin.

(2) Permohonan izin sebagaimana dimaksud pada ayat (1) dengan syarat:

a. mengajukan surat permohonan yang berisi identitas penanggung jawab kegiatan, bentuk kegiatan sosial, waktu pelaksanaan, jumlah peserta; dan

b. melampirkan proposal kegiatan.

(3) Jumlah peserta sebagaimana dimaksud pada ayat (2) huruf a harus disesuaikan dengan luas Bangunan Cagar Budaya, Struktur Cagar Budaya, Situs Cagar Budaya, dan Kawasan Cagar Budaya.

\section{Pemanfaatan untuk Kepentingan Pendidikan \\ Pasal 147}

(1) Pemanfaatan Cagar Budaya untuk kepentingan pendidikan sebagaimana dimaksud dalam Pasal 141 ayat (3) dapat dilakukan melalui kegiatan:

a. kemah budaya;

b. lokakarya; dan

c. kegiatan lainnya yang bertujuan meningkatkan pengetahuan, pemahaman, dan kesadaran masyarakat tentang Pelestarian Cagar Budaya.

(2) Pemanfaatan sebagaimana dimaksud pada ayat (1) harus tetap memperhatikan dan menghormati nilai yang terkandung dalam Cagar Budaya dan dapat meningkatkan apresiasi masyarakat terhadap Cagar Budaya.

(3) Pemanfaatan sebagaimana dimaksud pada ayat (1) dapat dilaksanakan pada semua Zona.

\section{Pasal 148}

(1) Pemanfaatan sebagaimana dimaksud dalam Pasal 147 didasarkan izin.

(2) Permohonan izin sebagaimana dimaksud pada ayat (1) dengan syarat:

a. mengajukan surat permohonan yang berisi identitas penanggung jawab kegiatan, bentuk kegiatan pendidikan, waktu pelaksanaan, jumlah peserta; dan

b. melampirkan proposal kegiatan.

(3) Jumlah peserta sebagaimana dimaksud pada ayat (2) huruf a harus disesuaikan dengan luas Bangunan Cagar Budaya, Struktur Cagar Budaya, Situs Cagar Budaya, dan Kawasan Cagar Budaya.

\section{Pemanfaatan untuk Kepentingan IImu Pengetahuan dan Teknologi \\ Pasal 149}

(1) Pemanfaatan Cagar Budaya untuk kepentingan ilmu pengetahuan dan teknologi sebagaimana dimaksud dalam Pasal 141 ayat (3) dapat dilakukan melalui kegiatan Penelitian dengan memanfaatkan Cagar Budaya sebagai objek Penelitian, serta kegiatan lain yang bertujuan untuk mengembangkan ilmu pengetahuan dan/atau teknologi.

(2) Pemanfaatan sebagaimana dimaksud pada ayat (1) harus tetap memperhatikan dan menghormati nilai yang terkandung dalam Cagar Budaya, meningkatkan apresiasi masyarakat terhadap Cagar Budaya, dan/atau meningkatkan ilmu pengetahuan dan/atau teknologi yang berbasis pada nilai-nilai kearifan budaya lokal.

(3) Pemanfaatan sebagaimana dimaksud pada ayat (1) dapat dilaksanakan pada semua Zona.

\section{Pasal 150}

(1) Pemanfaatan sebagaimana dimaksud dalam Pasal 149 didasarkan izin.

(2) Permohonan izin sebagaimana dimaksud pada ayat (1) dengan syarat:

a. mengajukan surat permohonan yang berisi identitas koordinator kegiatan, bentuk kegiatan kebudayaan, waktu pelaksanaan, dan jumlah peserta; dan

b. melampirkan proposal kegiatan.

(3) Jumlah peserta sebagaimana dimaksud pada ayat (2) huruf a harus disesuaikan dengan luas Bangunan Cagar Budaya, Struktur Cagar Budaya, Situs Cagar Budaya, dan Kawasan Cagar Budaya.

\section{Pemanfaatan untuk Kepentingan Kebudayaan}

Pasal 151

(1) Pemanfaatan Cagar Budaya untuk kepentingan kebudayaan sebagaimana dimaksud dalam Pasal 141 ayat (3) dapat dilakukan melalui kegiatan pagelaran, festival, pameran seni dan budaya, dan kegiatan lain yang bertujuan meningkatkan upaya Pelestarian, memperkuat identitas nilai budaya, serta meningkatkan promosi budaya.

(2) Pemanfaatan sebagaimana dimaksud pada ayat (1) harus tetap memperhatikan dan menghormati nilai yang terkandung dalam Cagar Budaya, meningkatkan apresiasi masyarakat terhadap Cagar Budaya dan kearifan lokal.

(3) Pemanfaatan sebagaimana dimaksud pada ayat (1) dapat dilaksanakan pada Zona Penyangga, Zona Pengembangan, Zona Pendukung, dan Zona Penunjang. 
(4) Pemanfaatan sebagaimana dimaksud pada ayat (1) untuk living monument dapat dilakukan pada semua Zona.

$$
\text { Pasal } 152
$$

(1) Pemanfaatan sebagaimana dimaksud dalam Pasal 151 didasarkan izin.

(2) Permohonan izin sebagaimana dimaksud pada ayat (1) dengan syarat:

a. mengajukan surat permohonan yang berisi identitas penanggung jawab kegiatan, bentuk kegiatan budaya, waktu pelaksanaan, dan jumlah peserta; dan

b. melampirkan proposal kegiatan.

(3) Jumlah peserta sebagaimana dimaksud pada ayat (2) huruf a harus disesuaikan dengan luas Bangunan Cagar Budaya, Struktur Cagar Budaya, Situs Cagar Budaya, dan Kawasan Cagar Budaya.

\section{Pemanfaatan untuk Kepentingan Pariwisata}

Pasal 153

(1) Pemanfaatan Cagar Budaya untuk kepentingan pariwisata sebagaimana dimaksud dalam Pasal 141 ayat (3) dapat dilakukan melalui kegiatan kunjungan wisata dan kegiatan lain yang bertujuan untuk wisata religi, wisata minat khusus, wisata arkeologi, atau wisata alam yang berkaitan dengan Cagar Budaya.

(2) Pemanfaatan sebagaimana dimaksud pada ayat (1) harus tetap memperhatikan dan menghormati nilai yang terkandung dalam Cagar Budaya, meningkatkan apresiasi masyarakat terhadap Cagar Budaya, dan kesejahteraan masyarakat.

(3) Pemanfaatan sebagaimana dimaksud pada ayat (1) dapat dilaksanakan pada semua Zona.

\section{Pasal 154}

(1) Pemanfaatan sebagaimana dimaksud dalam Pasal 153 untuk wisata arkeologi didasarkan izin.

(2) Permohonan izin sebagaimana dimaksud pada ayat (1) dengan syarat: a. mengajukan surat permohonan yang berisi identitas penanggung jawab kegiatan, bentuk kegiatan pariwisata, waktu pelaksanaan, dan jumlah peserta; dan

b. melampirkan proposal kegiatan dan mengisi surat pernyataan tentang kesanggupan untuk menjaga kelestarian Cagar Budaya sesuai peraturan perundang-undangan yang berlaku.

(3) Jumlah peserta sebagaimana dimaksud pada ayat (2) huruf a harus disesuaikan dengan luas Bangunan Cagar Budaya, Struktur Cagar Budaya, Situs Cagar Budaya, dan Kawasan Cagar Budaya.

\section{Izin dan Pelaksanaan Pemanfaatan}

\section{Pasal 15583}

(1) Izin Pemanfaatan Cagar Budaya diajukan kepada Menteri, gubernur, atau bupati/wali kota sesuai dengan kewenangannya.

(2) Gubernur atau bupati/wali kota sebagaimana dimaksud pada ayat (1) dapat melimpahkan kewenangannya kepada Instansi Pemerintah Daerah yang Berwenang di Bidang Pelestarian Cagar Budaya.

(3) Izin sebagaimana dimaksud pada ayat (1) dan ayat (2) dapat dicabut apabila pelaksanaan kegiatan Pemanfaatan Cagar Budaya tidak sesuai dengan tujuannya.

\section{Pasal 156}

Pelaksanaan Pemanfaatan Cagar Budaya harus dikonsultasikan kepada dan didampingi oleh Unit Pelaksana Teknis dan/atau Instansi Pemerintah Daerah yang berwenang di bidang Pelestarian Cagar Budaya sesuai dengan kewenangannya.

\section{Ketentuan pidana berdasar UU CB No. 11 Tahun 2010 tentang Cagar Budaya}

Pasal 111

Setiap orang yang tanpa izin pemilik dan/atau yang menguasainya, mendokumentasikan Cagar Budaya sebagaimana dimaksud dalam Pasal 92 dipidana dengan pidana penjara paling lama 5 (lima) tahun dan/atau denda paling banyak Rp500.000.000,00 (lima ratus juta rupiah).

\section{Pasal 112}

Setiap orang yang dengan sengaja memanfaatkan Cagar Budaya dengan cara perbanyakan sebagaimana dimaksud dalam Pasal 93 ayat (1) dipidana dengan pidana penjara paling lama 5 (lima) tahun dan/atau denda paling banyak Rp500.000.000,00 (lima ratus juta rupiah).

Segala bentuk kegiatan pemanfaatan harus didahului dengan izin kepada Pemerintah sesuai dengan kewenangannya. Gubernur atau bupati/wali kota dapat melimpahkan wewenangnya kepada instansi Pemerintah Daerah yang bergerak di bidang pelestarian cagar budaya. Selain itu apabila ternyata kegiatan pemanfaatan tidak sesuai dengan tujuannya maka izin dapat dicabut. Dalam memanfaatkan cagar budaya, pemanfaat harus didampingi oleh Unit Pelaksana Teknis atau instansi Pemerintah
Daerah yang berwenang di bidang pelestarian.

Dalam kegiatan pelestarian cagar budaya, terdapat sanksi hukum bagi setiap orang yang dengan sengaja mencegah, menghalang-halangi, atau menggagalkan upaya pelestarian, seperti yang diatur dalam Pasal 104 dengan pidana penjara paling lama 5 (lima) tahun dan/ atau denda paling sedikit Rp. 10.000.000,00 (sepuluh juta rupiah) dan paling banyak Rp 500.000.000,00 (lima ratus juta rupiah). 


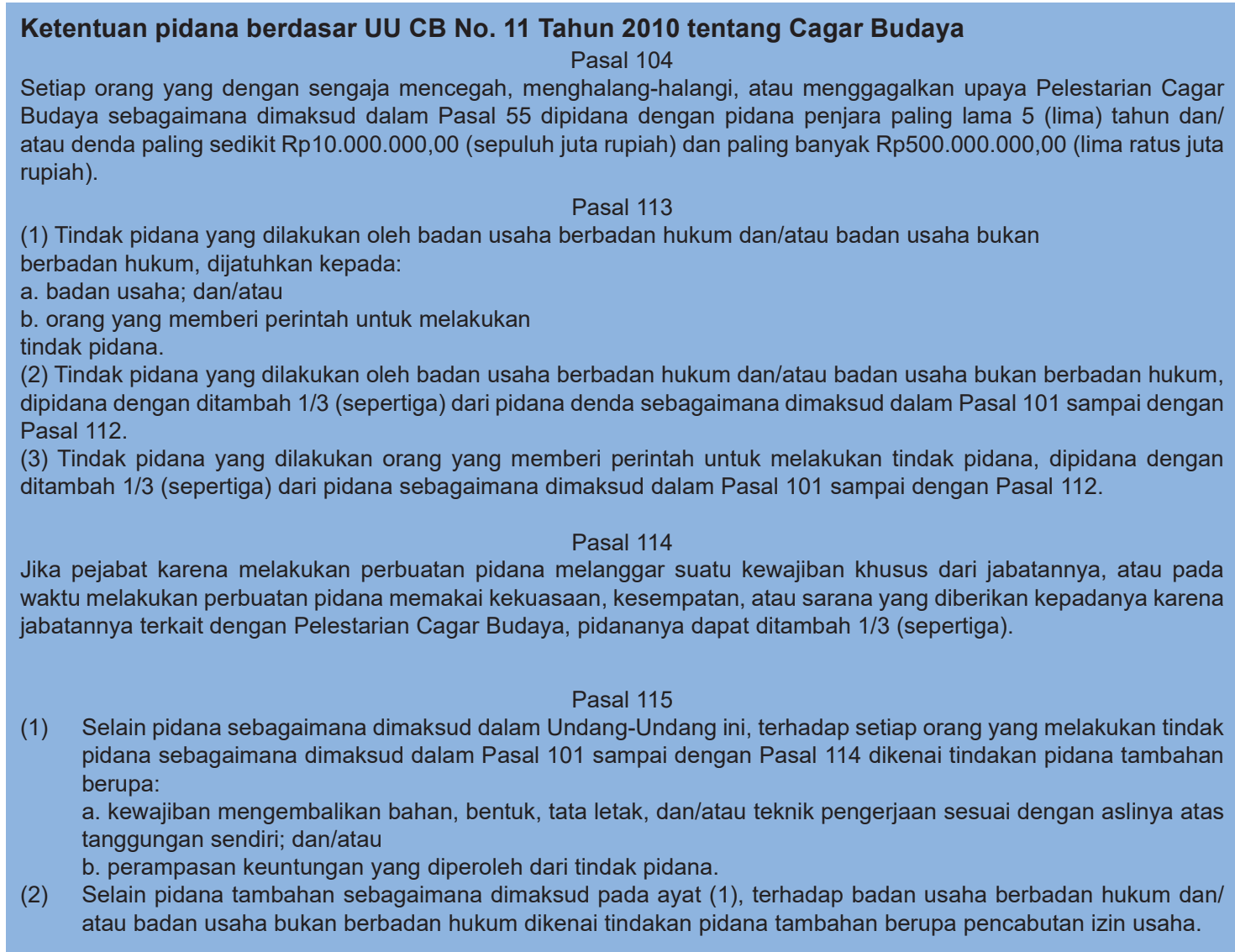

Terdapatkonsekuensi tambahan hukuman pidana bagi pejabat maupun badan usaha berbadan hukum dan/ atau yang bukan berbadan hukum yang melakukan tindak pidana, yaitu dipidana dengan ditambah 1/3 (sepertiga) dari pidana yang dijatuhkan. Hal ini diatur pada Pasal 113 dan 114 UU RI No. 11 Tahun 2010 tentang Cagar Budaya.

Pada Pasal 115 dijelaskan bahwa selain pidana sebagaimana dimaksud dalam Undang-Undang No. 11 Tahun 2010 tentang Cagar Budaya ini, terhadap setiap orang yang melakukan tindak pidana sebagaimana dimaksud dalam Pasal 101 sampai dengan Pasal 114 dikenai tindakan pidana tambahan berupa: a. kewajiban mengembalikan bahan, bentuk, tata letak, dan/atau teknik pengerjaan sesuai dengan aslinya atas tanggungan sendiri; dan/atau b. perampasan keuntungan yang diperoleh dari tindak pidana.

\section{Studi Kasus}

Salah satu contoh yang diambil untuk tulisan ini adalah Bangunan SMK Taman Ibu yang beralamatkan di Jl. Gadjah Mada No. 28 Yogyakarta. Bangunan ini berkaitan dengan kehidupan tokoh Pendidikan nasional Ki Hajar Dewantara selaku pendiri Taman Siswa. Keluarga Ki Hajar Dewantara tinggal di Jl. Gayam (sekarang Jl.
Gadjah Mada) dan mendirikan perguruan (sekolah) Taman Ibu yang merupakan cikal bakal berdirinya Taman Siswa yang pernah dijadikan tempat Kongres Taman Siswa yang pertama.

Karena memiliki arti penting bagi sejarah maka SMK Taman Ibu ini telah ditetapkan oleh Walikota Yogyakarta sebagai Bangunan Warisan Budaya tahun 2009 berdasarkan Undang-Undang Republik Indonesia Nomor 5 tahun 1992 tentang Benda Cagar Budaya (Keputusan Walikota Yogyakarta Nomor 798/ KEP/2009 tentang Penetapan Bangunan Warisan Budaya di Kota Yogyakarta). Namun seiring dengan berjalannya waktu bangunan tersebut kini telah musnah berganti dengan bangunan hotel berlantai 5 bernama Hotel Zest hanya dengan waktu yang singkat status cagar budaya disandangnya. Apa yang menjadikan peristiwa ini terjadi, sebuah bangunan cagar budaya peringkat kabupaten/ kota berubah menjadi bangunan hotel.

Sekolah SMK Taman Ibu merupakan Bangunan Warisan Budaya yang meliliki nilai penting dalam sejarah pendidikan Bangsa Indonesia. Seharusnya bangunan ini tetap dijaga dan dilestarikan keberadaannya apalagi telah berstatus Bangunan Warisan Budaya. Namun sayang hanya dalam waktu kurang lebih 4 tahun bangunan ini 
hilang musnah berganti wajah bangunan hotel.

Bangunan ini terletak di Jalan Gadjah Mada

No. 28 Yogyakarta. Sisi barat, timur, utara dan selatan dibatasi dengan pagar tembok setinggi $200 \mathrm{~cm}$. Pintu masuk terletak di sebelah barat. Daun pintu dibuat dari kayu berwarna hijau, terdiri dari dua daun pintu dan berukuran $200 \mathrm{~cm}$ x $138 \mathrm{~cm}$. Kompleks ini terdiri dari 5

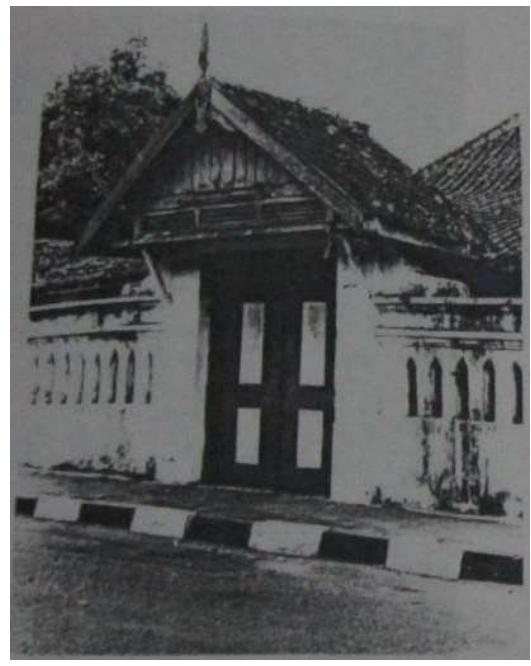

Detail pintu gerbang masuk dilihat dari barat daya. (Sumber: Anonim, 2002)

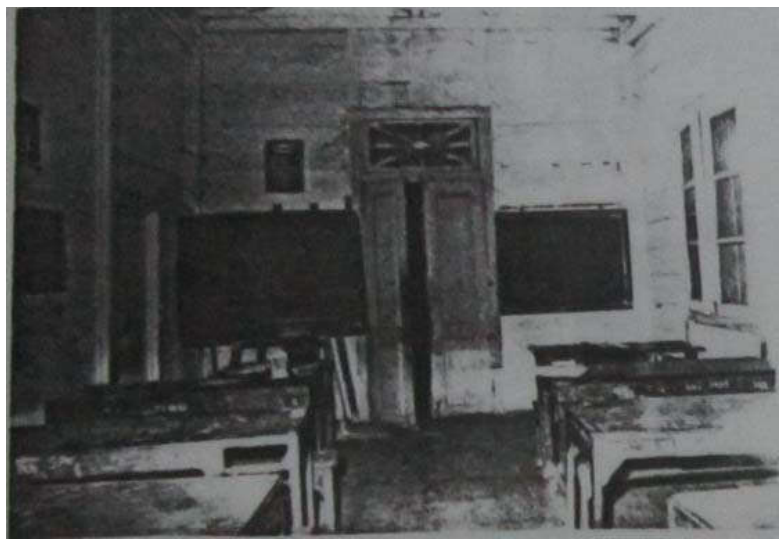

Situasi salah satu ruang belajar dilihat dari utara (Sumber: Anonim, 2002)

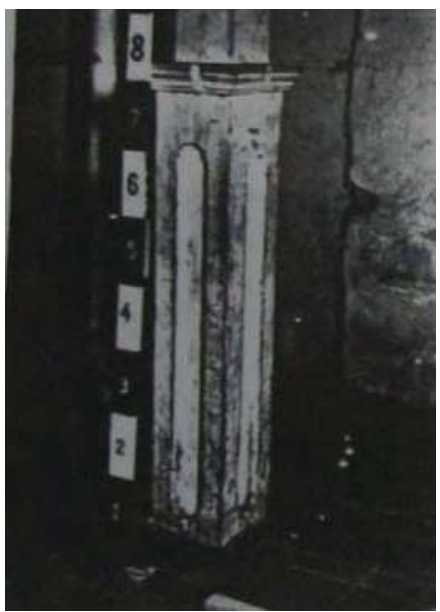

Datail salah satu tiang (Sumber: Anonim, 2002) buah bangunan yaitu:

a. Bangunan Induk

b. Bangunan Kelas

c. Bangunan Kantin

d. Bangunan Kelas

e. Sumur dan Dapur

f. Bangunan Ruang Guru

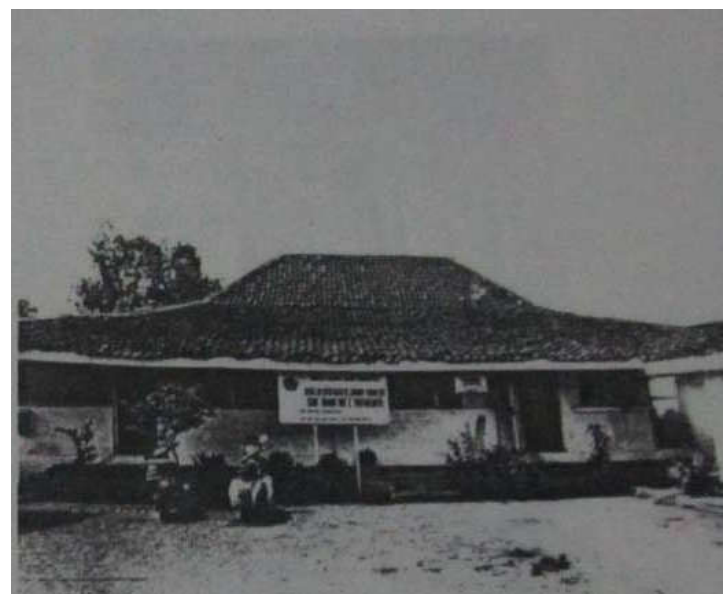

Situasi perguruan Taman Ibu dilihat dari barat (Sumber: Anonim, 2002)

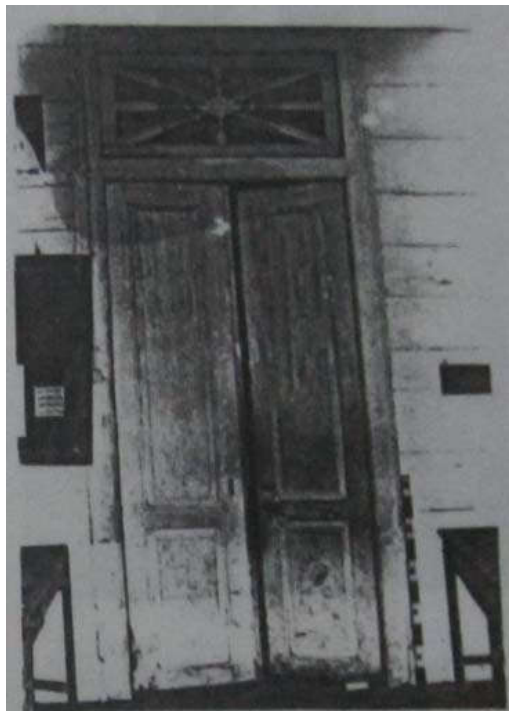

Detail pintu dengan ornamen hias dilihat dari utara. (Sumber: Anonim, 2002)

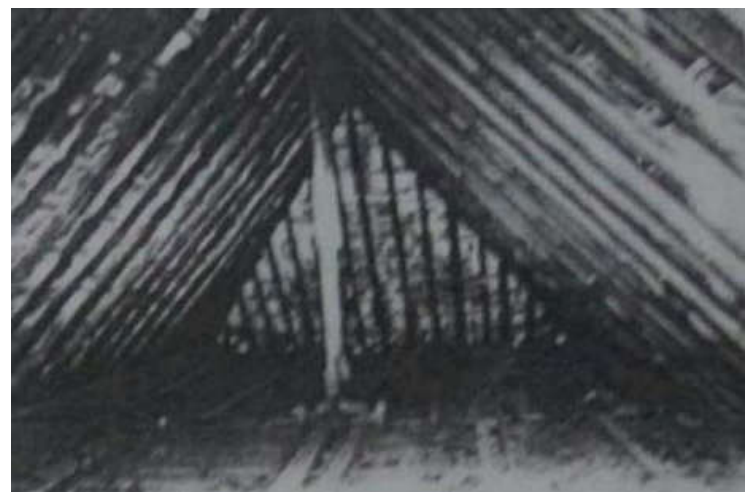

Detail struktur kuda-kuda penopang atap (Sumber: Anonim, 2002) 


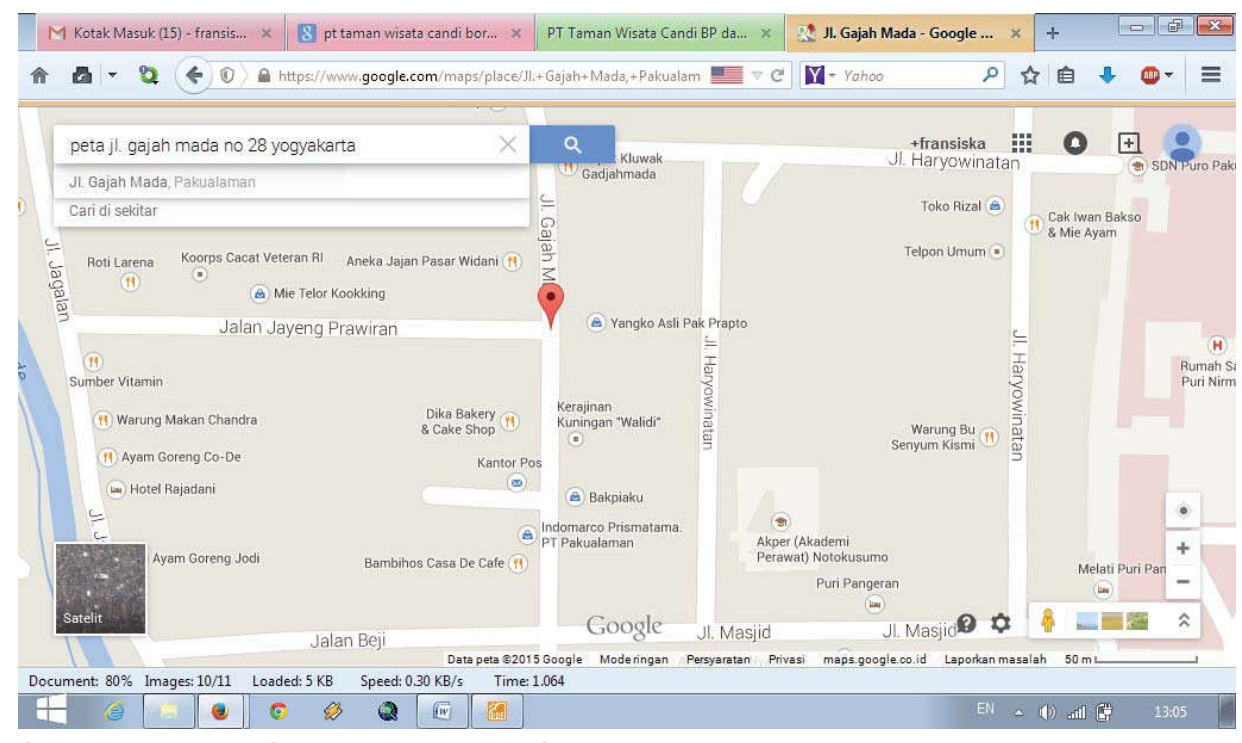

Gambar peta lokasi SMK Taman Ibu di JI. Gadjah Mada No. 28 Yogyakarta (Sumber: Google earth)

Bangunan sekolah taman Ibu yang terletak di Jl. Gadjah Mada No. 28 mempunyai sejarah atau riwayat yang panjang sebagai saksi bisu perjalanan hidup tokoh pendidikan nasional yaitu Ki Hajar Dewantara. Ini tidak lain karena bangunan tersebut pernah menjadi tempat tinggal dan cikal bakal lahirnya perguruan Taman Siswa.

Secara arsitektural bangunan tersebut bergaya tradisional Jawa, seperti bentuk pendoponya yang sudah berubah karena disekat-sekat dengan triplek atau kayu untuk kegiatan para siswa ataupun untuk ruangan para guru. Juga bentuk kuncungan pada gerbang masuk yang kelihatannya masih asli. Bagian dalamnya juga belum banyak berubah sehingga secara umum bangunan masih cukup baik.

Di dalam laporan yang dibuat oleh Suaka Peninggalan Sejarah dan Purbakala Daeah Istimewa Yogyakarta yang sekarang bernama Balai Pelestarian Cagar Budaya (BPCB) Yogyakarta tahun 2002 yang berjudul Laporan Pendataan Bangunan Sekolah Taman Ibu Yogyakarta dijelaskan mengenai sejarah berdirinya sekolah Taman Ibu. Sejarah berdirinya perguruan Taman Ibu di Yogyakarta tidak bisa dilepaskan dari peranan seorang tokoh pendidikan, yakni Soewardi Soeryaningrat. Beliau sebagai seorang bumi putera merasa resah melihat nasib bangsanya di bawah penindasan kolonial Belanda. Oleh karena itu dengan jalan tersendiri, beliau mencoba mengangkat harkat dan martabat bangsanya melalui jalur pendidikan dengan mendirikan sebuah sekolah (perguruan) dengan nama perguruan Taman Siswa. Soewardi Soeryaningrat sendiri kemudian lebih dikenal namanya sebagai Ki Hajar Dewantara.

Keluarga Ki Hajar Dewantara ini pada awalnya tinggal di Jl. Gayam (sekarang Jl. Gadjah Mada), setelah sukses mendirikan perguruan Taman Siswa, beliau bersama isterinya yakni R.Ay Soetartinah memikirkan sekolah lain. Ide tersebut terwujudkan dengan adanya Perguruan Taman Ibu. Perguruan tersebut merupakan lanjutan "Sekolah Taman Ibu Huishoud School" yang pertama di Indonesia. Sekolah ini didirikan pada tanggal 1 Agustus 1933 dengan menempati pendopo Suryokusumo di Bintaran Lor no. 5 Yogyakarta.

Di dalam laporan monitoring yang dibuat Balai Pelestraian Cagar Budaya (BPCB) Yogyakarta tahun 2009, bangunan yang digunakan SMK Taman Ibu sampai sekarang masih utuh dalam arti kondisi bangunan aslinya belum banyak mengalami perubahan, tentunya bangunan ataupun ruang tambahan disesuaikan dengan tuntutan kebutuhan. Namun demikian tidak menutup mata bahwa sebenarnya kondisi bangunan perguruan Taman Ibu kondisinya sudah sangat memprihatinkan. Banyak jendela atau pintu yang rusak dan kayu-kayunya telah lapuk dimakan rayap.

Berdasarkan Keputusan Walikota Yogyakarta Nomor 798/KEP/2009 tentang Penetapan Bangunan Warisan Budaya di Kota Yogyakarta, SMK Taman Ibu yang beralamat di Jl. Gadjah Mada No. 28 Yogyakarta, ditetapkan menjadi Bangunan Warisan Budaya berdasarkan usulan dari Balai Pelestarian Cagar Budaya (BPCB) Yogyakarta tahun 2008. Berdasarkan UndangUndang Republik Indonesia Nomor 11 Tahun 2010 
tentang Cagar Budaya, sebuah bangunan dapat ditetapkan menjadi cagar budaya harus memenuhi kriteria-kriteria yang terdapat pada Pasal 44 yang menyatakan:

Cagar Budaya dapat ditetapkan menjadi Cagar Budaya peringkat kabupaten/kota apabila memenuhi syarat:

a. Sebagai Cagar Budaya yang diutamakan untuk dilestarikan dalam wilayah kabupaten/kota;

b. Mewakili masa gaya yang khas;

c. Tingkat keterancamannya tinggi;

d. Jenisnya sedikit; dan/atau

e. Jumlahnya terbatas.

Bangunan SMK Taman Ibu layak dijadikan cagar budaya karena berdasarkan sejarah pendiriannya merupakan cikal bakal lahirnya Taman Siswa yang didirikan oleh Tokoh Pendidikan Nasional Ki Hajar
Dewantara.

Pemeringkatan sebuah cagar budaya berdasarkan kepentingannya, dilakukan oleh Pemerintah dan Pemerintah Daerah berdasarkan rekomendasi dari Tim Ahli Cagar Budaya seperti yang telah diatur pada Pasal 41 Undang-Undang RI Nomor 11 Tahun 2010 tentang Cagar Budaya.

Berdasarkan hasil monitoring yang dilakukan oleh Balai Pelestarian Cagar Budaya (BPCB) Yogyakarta tanggal 10 Oktober 2009, bangunan SMK Taman Ibu dalam kondisi kosong dan tidak terawat dikarenakan pemilik bangunan meminta pihak yayasan untuk pindah. Bangunan bekas perguruan Taman Ibu tersebut milik Bapak Istichfar, dan berada dalam satu lokasi dengan rumah Bapak Istichfar. Bangunan dibatasi oleh pagar tembok setinggi 2 meter, dengan pintu masuk berada

\section{Berikut ini adalah kronologi mengenai status SMK Taman Ibu sebagai Bangunan Warisan Budaya.}

\begin{tabular}{|c|c|c|}
\hline No. & Tanggal & Keterangan \\
\hline 1. & Tahun 2008 & $\begin{array}{l}\text { SMK Taman Ibu diusulkan menjadi Cagar Budaya oleh Balai Pelestarian Cagar } \\
\text { Budaya (BPCB) Yogyakarta. }\end{array}$ \\
\hline 2. & 28 November 2009 & $\begin{array}{l}\text { SMK Taman Ibu ditetapkan sebagai Bangunan Warisan Budaya oleh Walikota } \\
\text { Yogyakarta berdasarkan Surat Keputusan Walikota Yogyakarta Nomor 798/KEP/2009 } \\
\text { tentang Penetapan Bangunan Warisan Budaya di Kota Yogyakarta }\end{array}$ \\
\hline 3. & 18 Oktober 2012 & $\begin{array}{l}\text { Sdr. I Wayan Sudiarsa yang beralamat di BR. Dinas Dalem, Kerobokan, Sawan, } \\
\text { Buleleng, Bali, mengajukan permohonan Izin Membangunan Bangun Bangunan } \\
\text { (IMBB) berupa hotel di Jl. Gadjah Mada } 28 \text { Yogyakarta }\end{array}$ \\
\hline 4. & 5 April 2013 & $\begin{array}{l}\text { Dibuat Berita Acara Rekomendasi Bentuk Arsitektur Bangunan oleh Tim Pertimbangan } \\
\text { Pelestarian Warisan Budaya (TP2WB) Kota Yogyakarta terhadap Rencana } \\
\text { Pembangunan Bangunan di Jl. Gadjah Mada No.28 Purwokinanti Yogyakarta, Nomor: } \\
430 / 009\end{array}$ \\
\hline 5. & 11 April 2013 & $\begin{array}{l}\text { Dikeluarkan surat dari Dinas Pariwisata dan kebudayaan Pemerintah Kota Yogykarta, } \\
\text { perihal: Rekomendasi Bentuk Arsitektur Bangunan, kepada: Sdr. I Wayan Sudiarsa, } \\
\text { BR. Dinas Dalem, Kerobokan, Sawan, Buleleng, Bali, dengan nomor surat: 430/271. }\end{array}$ \\
\hline 6. & 2 Januari 2015 & $\begin{array}{l}\text { Penulis mengmbil foto bangunan Hotel Zest di JI. Gadjah Mada No. } 28 \text { Yogyakarta, } \\
\text { seperti terlihat di bawah ini. }\end{array}$ \\
\hline
\end{tabular}
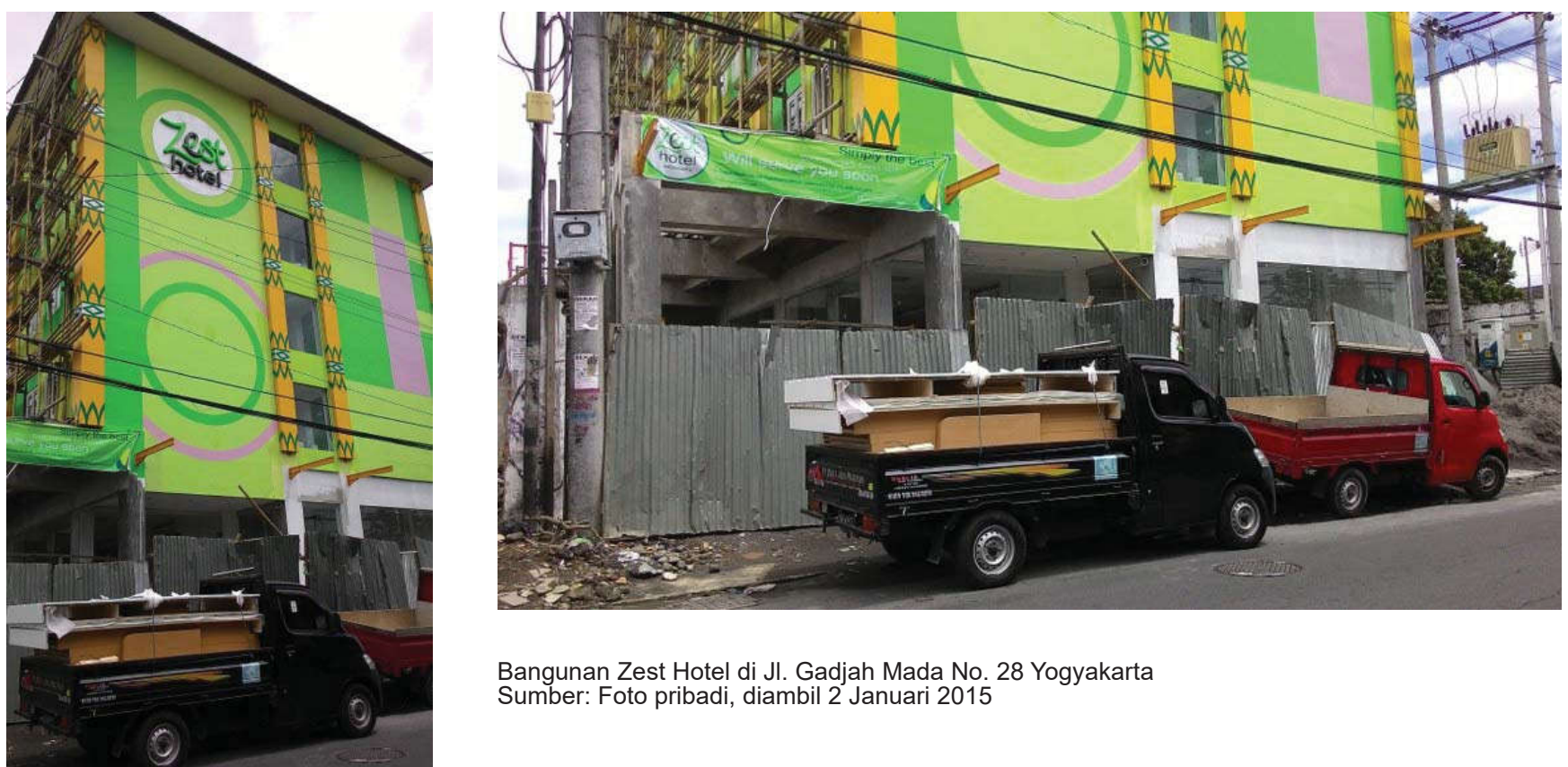

Bangunan Zest Hotel di Jl. Gadjah Mada No. 28 Yogyakarta Sumber: Foto pribadi, diambil 2 Januari 2015 
di sisi barat. Bangunan induk menghadap ke barat, berbentuk joglo yang sudah disekat-sekat menjadi ruang tertutup, dimana dinding bangunan sisi barat berupa tembok plesteran, dinding sisi timur berbentuk kotangan, dinding utara berupa papan kayu. Atap bangunan dari genteng tanah liat.

Di sebelah selatan bangunan pendopo yang sudah berubah bentuk tersebut, terdapat bangunan yang kemungkinan besar merupakan penambahan baru. Di sebelah utara bangunan induk berupa lahan kosong yang merupakan bekas bangunan yang telah dirobohkan. Kondisi keseluruhan perguruan Taman Ibu tampak memprihatinkan dan tidak terawat.

Jika dilihat dari status kepemilikan bangunan SMK Taman Ibu adalah milik Bapak Istichfar, berarti hak milik pribadi. Pada tanggal 28 November 2009, bangunan ini ditetapkan sebagai Bangunan Warisan Budaya oleh Walikota Yogyakarta dengan Nomor 798/KEP/2009 tentang Penetapan Bangunan Warisan Budaya di Kota Yogyakarta. Dengan kata lain telah ditetapkan sebagai cagar budaya peringkat kabupatan/kota.

Ternyata pada tanggal tanggal 18 Oktober 2012 seorang bernama I Wayan Sudiarsa yang beralamat di BR. Dinas Dalem, Kerobokan, Sawan, Buleleng, Bali telah mengajukan surat permohonan Izin Membangunan Bangun Bangunan (IMBB) berupa hotel di Jl. Gadjah Mada No. 28 Yogyakarta. Surat Permohonan ini kemudian ditindaklanjuti dengan adanya Berita Acara Rekomendasi Bentuk Arsitektur Bangunan oleh Tim Pertimbangan Pelestarian Warisan Budaya (TP2WB) Kota Yogyakarta terhadap Rencana Pembangunan Bangunan di Jl. Gadjah Mada No.28 Purwokinanti Yogyakarta, tanggal 5 April 2013 dengan Nomor: 430/009. Dasar Pertimbangan yang dipakai dalam penyusunan Berita Acara ini adalah:

1. Bangunan ini terletak di Kawasan Cagar Budaya (KCB) Pakualaman Yogyakarta. Dalam rangka pengurusan Izin Membangunan Bangun Bangunan (IMBB), harus dimintakan Rekomendasi terkait dengan ketentuan yang berlaku.

2. Bangunan akan didirikan pada lahan bekas SMK Taman Ibu yang telah memiliki status Bangunan Cagar Budaya berdasarkan Keputusan Walikota Yogyakarta Nomor 798 tahun 2009.

Kemudian dalam subbab Rekomendasi terhadap usulan desain bangunan, dinyatakan:

a. Dikarenakan bangunan tersebut didirikan pada lahan bekas sebuah bangunan warisan budaya, maka pemohon harus menyediakan sebuah media khusus yang ditempatkan di lobi hotel yang berisi tentang segala informasi tentang SMK Taman Ibu baik dalam bentuk naratif deskriptif maupun piktorial.

b. Untuk selanjutnya diperingatkan kepada pemohon apabila akan melakukan pembangunan di Kota Yogyakarta untuk mengurus administrasi perizinan terlebih dahulu sebelum melakukan pembongkaran sehingga kasus penghancuran bangunan warisan budaya yang terjadi di Jl. Gadjah Mada 28 tidak terjadi lagi.

Pada tahun 2014 di tempat lokasi Jl. Gadjah Mada No. 28 telah dibangun bangunan hotel yang sampai saat

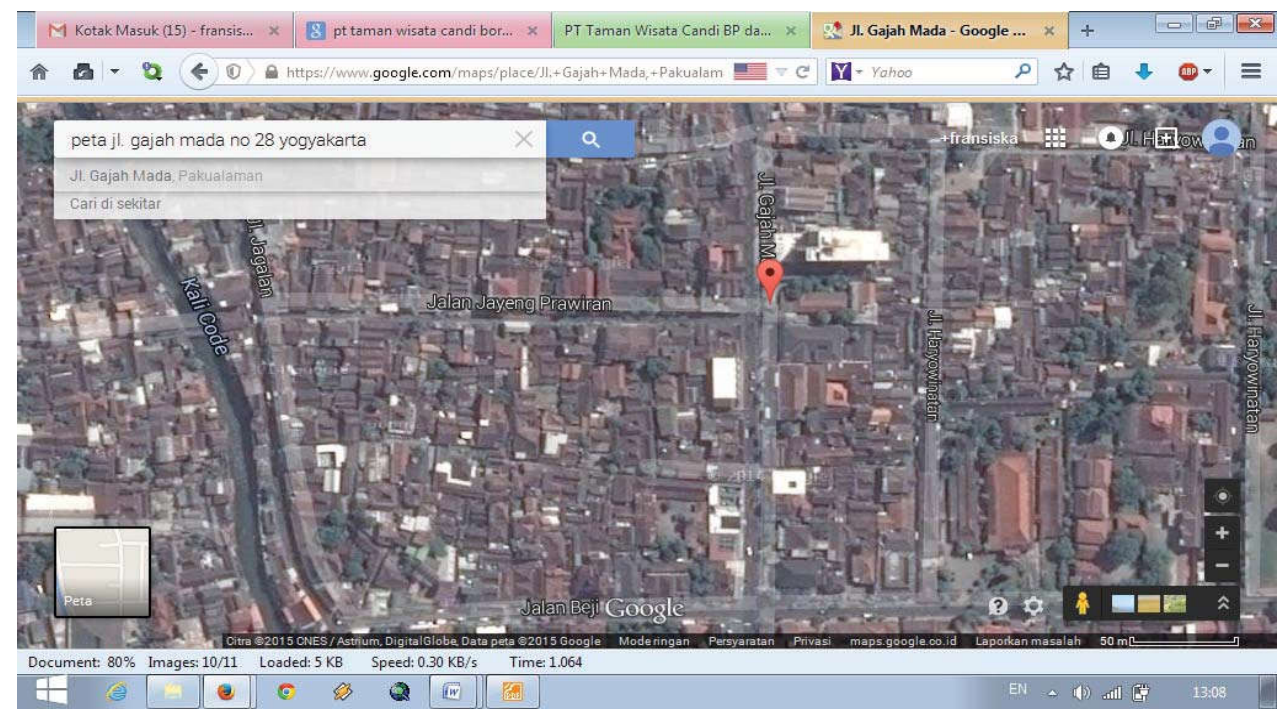

Peta Lokasi Hotel Zest yang sebelumnya SMK Taman Ibu Sumber: Google earth 
ini belum selesai pembangunannya. Tahap pembangunan sampai dengan tanggal 2 Januari 2015 adalah bangunan sudah berlantai 5 dan sepertinya tinggal finishing cat bagian dalam bangunan. Berdasarkan informasi website dari hotel ini, bangunan hotel akan di launching pada tahun 2015 ini. Dengan dibangunnya bangunan hotel yang bernama Zest Hotel dengan berlantai 5 ini, berarti telah muncul izin IMBB dari Dinas Perizinan Pemerintah Kota Yogyakarta.

Berdasarkan kronologis di atas, dapat ditarik benang merah bahwa status kepemilikan bangunan SMK Taman Ibu yang semula dimiliki oleh Bapak Istichfar, pada tahun 2012 telah berpindah tangan, kemungkinan dibeli oleh a.n. I Wayan Sudiarsa yang beralamat di BR. Dinas Dalem, Kerobokan, Sawan, Buleleng, Bali. Kemudian Sdr. I Wayan Sudiarsa mengajukan surat permohonan IMBB berupa hotel kepada Dinas Perizinan Kota Yogyakarta. Sebelum izin IMBB turun, telah dilakukan pembongkaran bangunan SMK Taman Ibu tanpa didahului mengajukan surat izin pembongkaran bangunan yang berupa cagar budaya.

Berdasarkan informasi dari Balai Pelestarian Cagar Budaya (BPCB) Yogyakarta, memang pernah ada kabar bahwa pemilik bangunan yaitu Bapak Istichfar meminta bangunan SMK Taman Ibu untuk dicabut statusnya sebagai cagar budaya, namun kondisi selanjutnya tidak diketahui kabar beritanya, yang belakangan ini diketahui bahwa telah berdiri bangunan hotel di tempat tersebut. Namun melihat Dasar Pertimbangan dari Berita Acara TP2WP yang menyatakan status lahan bekas SMK Taman Ibu sebagai Bangunan Warisan Budaya, berarti statusnya masih tetap cagar budaya dan belum dihapus.

Dalam hal kepemilikan cagar budaya telah diatur dalan UU RI Nomor 11 tahun 2010 tentang Cagar Budaya Pasal 16 ayat (1), cagar budaya yang dimiliki setiap orang dapat dialihkan kepemilikannya kepada negara atau setiap orang lain. Dan pada ayat (3), pengalihan kepemilikan sebagaimana dimaksud pada ayat (1) dapat dilakukan dengan cara diwariskan, dihibahkan, ditukarkan, dihadiahkan, dijual, diganti rugi, dan/atau penetapan atau putusan pengadilan. Pada Pasal 17 dinyatakan ayat (1), dinyatakan setiap orang dilarang mengalihkan kepemilikan Cagar Budaya peringkat nasional, peringkat provinsi, atau peringkat kabupaten/kota, baik seluruh maupun bagianbagiannya, kecuali dengan izin Menteri, gubernur, atau bupati/wali kota sesuai dengan tingkatannya. Dalam kasus ini jika pemilik awal yaitu Bapak Istichfar tidak ijin mengalihkan kepemilikan cagar budaya kepada Sdr. I Wayan Sudiarsa dapat dikenakan pidana sesuai Pasal 101, setiap orang yang tanpa izin mengalihkan kepemilikan Cagar Budaya sebagaimana dimaksud dalam Pasal 17 ayat (1) dipidana dengan pidana penjara paling singkat 3 (tiga) bulan dan paling lama 5 (lima) tahun dan/atau denda paling sedikit Rp400.000.000,00 (empat ratus juta rupiah) dan paling banyak Rp1.500.000.000,00 (satu miliar lima ratus juta rupiah).

Dengan berdirinya bangunan Hotel Zest ini berarti telah keluar izin IMBB dari Dinas Perizinan Kota Yogyakarta, yang mengizinkan membangun hotel di lahan bekas SMK Taman Ibu. Apa dasar yang melatarbelakangi dikeluarkannya izin tersebut? Apakah karena bangunan ini terlebih dahulu telah dibongkar oleh pemilik yang baru a.n. I Wayan Sudiarsa, sehingga terlanjur sudah roboh bangunannya. Jika pemilik pertama (Bapak Istichfar) telah pengajukan izin tentang pengalihan kepemilikan cagar budaya kepada pemilik kedua (Sdr. I Wayan Sudiarsa), berarti pemilik kedua telah mengetahui bahwa status bangunan yang dibelinya adalah cagar budaya. Dan telah terjadi pembongkaran bangunan warisan budaya SMK Taman Ibu tanpa sebelumnya mengajukan izin pembongkaran maka Sdr. I Wayan Sudiarsa telah melanggar Pasal 55 UU RI Nomor 11 tahun 2010 tentang Cagar Budaya, yaitu setiap orang dilarang dengan sengaja mencegah, menghalang-halangi, atau menggagalkan upaya Pelestarian Cagar Budaya. Sehingga dapat dipidana sesuai Pasal 104, yang menyatakan setiap orang yang dengan sengaja mencegah, menghalang-halangi, atau menggagalkan upaya Pelestarian Cagar Budaya sebagaimana dimaksud dalam Pasal 55 dipidana dengan pidana penjara paling lama 5 (lima) tahun dan/atau denda paling sedikit Rp10.000.000,00 (sepuluh juta rupiah) dan paling banyak Rp500.000.000,00 (lima ratus juta rupiah).

Selain dengan Pasal 55, Sdr. I Wayan Sudiarsa juga dapat dikenakan Pasal 66 ayat (1), setiap orang dilarang merusak Cagar Budaya, baik seluruh maupun bagian-bagiannya, dari kesatuan, kelompok, dan/atau dari letak asal. Dengan ancaman pidananya sesuai dengan Pasal 105, yaitu setiap orang yang dengan sengaja merusak Cagar Budaya sebagaimana dimaksud dalam Pasal 66 ayat (1) dipidana dengan pidana penjara paling singkat 1 
(satu) tahun dan paling lama 15 (lima belas) tahun dan/ atau denda paling sedikit Rp500.000.000,00 (lima ratus juta rupiah) dan paling banyak Rp5.000.000.000,00 (lima miliar rupiah).

Dengan dibongkarnya bangunan SMK Taman Ibu dan berdirinya Hotel Zest di lokasi Jl. Gadjah Mada No. 28 Yogyakarta ini, berarti status Bangunan SMK Taman Ibu sebagai Bangunan Warisan Budaya secara otomatis dicabut peringkatnya sebagai cagar budaya karena telah musnah, seperti yang telah diatur dalam Pasal 48, yang menyatakan bahwa Peringkat Cagar Budaya dapat dicabut apabila Cagar Budaya:

a. musnah;

b. kehilangan wujud dan bentuk aslinya;

c. kehilangan sebagian besar unsurnya; atau

d. tidak lagi sesuai dengan syarat sebagaimana dimaksud dalam Pasal 42, Pasal 43, atau Pasal 44.

Sungguh sayang bangunan warisan budaya yang telah ditetapkan sebagai cagar budaya perigkat Kabupaten/kota hilang berganti dengan hotel. Ada beberapa syarat suatu warisan budaya dapat diusulkan sebagai cagar budaya salah satu diantaranya adalah harus mempunyai arti khusus atau nilai penting bagi sejarah, ilmu pengetahuan, pendidikan, agama, dan/ atau kebudayaan (Undang-Undang Republik Indonesia Nomor 11 Tahun 2010 tentang Cagar Budaya. Menurut Daud, dalam penentuan kriteria Cagar Budaya suatu warisan budaya memiliki nilai penting sejarah apabila sumber daya budaya tersebut dapat menjadi bukti yang berbobot dari peristiwa yang terjadi pada masa prasejarah dan sejarah, berkaitan erat dengan tokoh-tokoh sejarah, atau menjadi bukti perkembangan penting dalam bidang tertentu. Bangunan sekolah Taman Ibu memiliki nilai penting bagi sejarah perkembangan pendidikan di Kota Yogyakarta yaitu sebagai cikal bakal berdirinya Taman Siswa. Hal ini juga berkaitan erat dengan kehidupan pahlawan nasional Ki Hajar Dewantoro sebagai seorang tokoh pendidikan.

\section{Kesimpulan}

Pada dasarnya seluruh kegiatan pelestarian yang meliputi pelindungan, pengembangan dan pemanfaatan cagar budaya harus didahului dengan izin kepada Pemerintah sesuai dengan kewenangannya (Menteri, gubernur, bupati/wali kota). Pemerintah dapat melimpahkan wewenangnya kepada unit Pelaksana
Teknis atau Pemerintah Daerah yang bergerak dibidang pelestarian cagar budaya.

Pemberian izin dapat dibatalkan atau dicabut apabila dalam pelaksanaan kegiatan pelindungan, pengembangan dan pemanfaatan cagar budaya ternyata melenceng dari tujuan semula. Terdapat konsekuensi hukum bagi orang yang melakukan kegiatan pelestarian tanpa izin.

Memang sebuah tantangan besar bagi Bangsa Indonesia dalam melestarikan cagar budaya yang dihadapkan dengan perkembangan zaman dan tekanan pembangunan. Merupakan sebuah pelajaran yang berharga yang dapat kita ambil dari peristiwa yang terjadi dengan bangunan SMK Taman Ibu yang telah berstatus Bangunan Warisan Budaya yang kebetulan status kepemilikannya merupakan milik pribadi.

Dengan adanya Undang-Undang Republik Indonesia Nomor 11 tahun 2010 tentang Cagar Budaya, pemilik cagar budaya berkewajiban untuk menjaga dan memelihara cagar budaya yang dimilikinya, walaupun pada kenyataannya banyak yang merasa keberatan berkaitan dengan biaya pemeliharaannya yang tidak sedikit. Walaupun telah diberikan kompensasi dan insentif bagi yang telah melindungi cagar budaya miliknya, kadang orang tetap berorientasi pada nilai ekonomi yang terkandung dalam cagar budaya tersebut.

Pemilik bangunan SMK Taman Ibu menjual kepada pihak lain karena mungkin selain biaya untuk pemeliharaan bangunannya mahal, pembeli/investor berani membeli dengan harga yang tinggi sehingga pemilik tergiur untuk menjual cagar budaya miliknya yang berakibat belum tentu selanjutnya terawat kondisi cagar budaya tersebut.

Perusakan ataupun pembiaran cagar budaya yang dilakukan dengan sengaja oleh pihak tertentu untuk mencapai tujuan tertentu juga seharusnya mendapatkan pidana yang sesuai dengan perbuatannya sehingga dapat menjadi pembelajaran dan kesadaran bagi masyarakat dalam melestarikan cagar budaya. Dalam hal bangunan SMK Taman Ibu ini penulis menduga adanya unsur kesengajaan dalam membongkar/merobohkan bangunan karena asumsinya pemilik baru telah mengetahui statusnya sebagai bangunan warisan budaya, dan melakukannya tanpa didahului dengan izin terlebih dulu. Dengan tidak adanya tindakan hukum yang tegas terhadap tindakan 
tersebut, bisa saja dianggap bahwa kejadian seperti itu adalah salah satu cara cepat untuk memusnahkan cagar budaya untuk kepentingan tertentu dengan alasan ketidaktahuan akan hukum yang berlaku.

Selain itu diperlukan juga pengawasan terhadap pelestarian cagar budaya oleh pemerintah dan pemerintah daerah sekaligus sosilalisasinya kepada masyarakat luas sehingga masyarakat juga mengetahui dan berperan aktif untuk melestarikan cagar budaya.

\section{DAFTAR PUSTAKA}

Anonim. 2002. Laporan Pendataan Bangunan Sekolah Taman Ibu Yogyakarta. Suaka Peninggalan Sejarah dan Purbakala Daeah Istimewa Yogyakarta. Direktorat Jenderal Kebudayaan. Departemen Pendidikan dan Kebudayaan.

Anonim. 2009. Laporan Monitoring Kawasan Tabun 2009. Balai Pelestarian Peninggalan Purbakala Yogyakarta

Berita Acara Rekomendasi Bentuk Arsitektur Bangunan Tim Pertimbangan Pelestarian Warisan Budaya (TP2WB) Kota Yogyakarta Terhadap Rencana Pembangunan di Jl. Gadjah Mada No.28 Purwokinanti Yogyakarta Nomor: 430/009 tanggal 5 April 2013

Draf RPP Pelestarian Cagar Budaya (per September 2014)
Keputusan Walikota Yogyakarta Nomor 798/KEP/2009 tentang Penetapan Bangunan Warisan Budaya di Kota Yogyakarta. Pemerintah Kota Yogyakarta Tanudirjo, D.A. 2004. Kriteria Penetapan Benda Cagar Budaya. Makalah disampaikan di acara Wokshop Pedoman Penetapan Benda Cagar Budaya diselenggarakan oleh Deputi Menteri Bidang Kepurbakalaan dan Museum. Departemen Kebudayaan dan Pariwisata di Cirebon, 16-18 Juni 2004

Republik Indonesia. 2010. Undang-Undang Republik Indonesia Nomor 11 Tahun 2010 tentang Cagar Budaya 